\title{
The fossil flora and age of the Wamsutta red beds (Middle Pennsylvanian), Narragansett Basin, southeastern Massachusetts, USA and correlation with the Cumberland Group of the Maritime Provinces of Canada
}

\author{
Paul C. Lyons et Robert G. Sproule
}

Volume 54, 2018

URI : https://id.erudit.org/iderudit/1055420ar

DOI : https://doi.org/10.4138/atlgeol.2018.011

Aller au sommaire du numéro

Éditeur(s)

Atlantic Geoscience Society

ISSN

0843-5561 (imprimé)

1718-7885 (numérique)

Découvrir la revue

Citer cet article

Lyons, P. \& Sproule, R. (2018). The fossil flora and age of the Wamsutta red beds (Middle Pennsylvanian), Narragansett Basin, southeastern Massachusetts, USA and correlation with the Cumberland Group of the Maritime Provinces of Canada. Atlantic Geology, 54, 315-334. https://doi.org/10.4138/atlgeol.2018.011
Résumé de l'article

New collections of plant macrofossils provide a precise Middle Pennsylvanian age for the lower Wamsutta Formation red beds of the Narragansett Basin, southeastern Massachusetts, USA. The Wamsutta assemblage indicates strong correlation with the Cumberland Group of the Maritimes Provinces of Canada, which was earlier considered to be of late Langsettian to early Duckmantian age. This correlation is supported by the presence in the Wamsutta Formation of the following plant-fossil species: Neuralethopteris schlehanii, Neuropteris obliqua, Senftenbergia plumosa, Calamites suckowii, Annularia asteris, Annularia cf. microphylla,Asterophyllites charaeformis, Asterophyllites grandis, Asterophyllites lindleyanus, Sphenophyllum cuneifolium, and Sphenopteris valida. Moreover, the new fossil flora resembles the Middle Pennsylvanian florules of western Europe, such as the Laveineopteris loshii Subzone. The new flora is especially similar to those of the Iberian Peninsula, where there is a complete succession of Carboniferous macrofloral zones, and this similarity confirms a late Langsettian or early Duckmantian age for the lower Wamsutta macroflora. The new collections of Wamsutta Formation plant fossils, along with a smaller existing collection, represent the oldest known macroflora in the Narragansett Basin. 


\title{
The fossil flora and age of the Wamsutta Formation red beds (Middle Pennsylvanian), Narragansett Basin, southeastern Massachusetts, USA and correlation with the Cumberland Group of the Maritime Provinces of Canada
}

\author{
Paul C. Lyons ${ }^{1^{*}}$ And Robert G. Sproule ${ }^{2 \dagger}$ \\ 1. 40 Robert F. Toner Boulevard, Unit 102A, North Attleboro, Massachusetts 02763, USA \\ 2. 40 Paulette Terrace, Plymouth, Massachusetts, 02360-6852, USA \\ ${ }^{*}$ Corresponding author \\ $\dagger$ deceased
}

Date received: 28 June 2017 Date accepted 24 January 2018

\begin{abstract}
New collections of plant macrofossils provide a precise Middle Pennsylvanian age for the lower Wamsutta Formation red beds of the Narragansett Basin, southeastern Massachusetts, USA. The Wamsutta assemblage indicates strong correlation with the Cumberland Group of the Maritime Provinces of Canada, which was earlier considered to be of late Langsettian to early Duckmantian age. This correlation is supported by the presence in the Wamsutta Formation of the following plant-fossil species: Neuralethopteris schlehanii, Neuropteris obliqua, Senftenbergia plumosa, Calamites suckowii, Annularia asteris, Annularia cf. microphylla, Asterophyllites charaeformis, Asterophyllites grandis, Asterophyllites lindleyanus, Sphenophyllum cuneifolium, and Sphenopteris valida. Moreover, the new fossil flora resembles the Middle Pennsylvanian florules of western Europe, such as the Laveineopteris loshii Subzone. The new flora is especially similar to those of the Iberian Peninsula, where there is a complete succession of Carboniferous macrofloral zones, and this similarity confirms a late Langsettian or early Duckmantian age for the lower Wamsutta macroflora. The new collections of Wamsutta Formation plant fossils, along with a smaller existing collection, represent the oldest known macroflora in the Narragansett Basin.
\end{abstract}

\section{RÉSUMÉ}

De nouvelles collections de macrofossiles végétaux fournissent unâge plus précis correspondant au Pennsylvanien moyen en ce qui concerne les couches rouges de la partie inférieure de la formation de Wamsutta dans le bassin de Narragansett, dans le sud-est du Massachusetts, aux États-Unis. L'assemblage de Wamsutta indique une corrélation étroite avec le groupe de Cumberland des provinces maritimes canadiennes qui était antérieurement considéré comme un assemblage remontant à l'époque du Langsettien tardif au Duckmantien précoce. Cette corrélation est appuyée par la présence des espèces fossiles végétales suivantes dans la formation de Wamsutta : Neuralethopteris schlehanii, Neuropteris obliqua, Senftenbergia plumosa, Calamites suckowii, Annularia asteris, Annularia cf. microphylla, Asterophyllites charaeformis, Asterophyllites grandis, Asterophyllites lindleyanus, Sphenophyllum cuneifolium et Sphenopteris valida. De plus, la nouvelle flore fossile ressemble aux florules du Pennsylvanien moyen d'Europe occidentale, comme celles de la sous-zone Laveineopteris loshii. La nouvelle flore est particulièrement semblable à celle de la péninsule Ibérique, où l'on trouve une succession complète de macroflorizones du Carbonifère, et cette similarité confirme que la macroflore de la partie inférieure de Wamsutta remonte au Langsettien tardif ou au Duckmantien précoce. Les nouvelles collections de fossiles végétaux de la formation de Wamsutta, tout comme une collection existante plus restreinte, représentent la macroflore la plus ancienne connue dans le bassin de Narragansett.

[Traduit par la redaction]

\section{INTRODUCTION}

The Wamsutta Formation red beds of the Narragansett Basin contain sparse plant fossils. Shaler et al. (1899) re- ported Calamites and Cordaites, which demonstrate that the Wamsutta Formation is of Carboniferous (Pennsylvanian) age, like the overlying Rhode Island Formation. Further substantial progress on the paleobotany of the Wamsutta 
Formation was not made until Knox (1944) reported the following florule from the lower Wamsutta Formation: $A n$ nularia stellata; Calamocladus (= Asterophyllites longifolius); Calamites equisetiformis (= Asterophyllites equisetiformis); Calamites suckowii; Pecopteris sp.; Neuropteris cf. N. rarinervis (probably a misidentification); Sphenopteris valida; Sphenopteris sp.; Oligocarpa splendens; Cordaites cf. C. robbii; Cordaites cf. C. communis; "Sigillarian leaves" (lycopsid leaves $=$ Cyperites).

Two problems exist with Knox's (1944) collection. First, he provided no photographs or drawings of the specimens that he collected to help validate his identifications. Second, we do not know where Knox's collection is located. A recent thorough search of the paleobotanical collections at Harvard University revealed no sign of the collection ever having been housed there. Inquiries as to whether the collection perhaps had been deposited in the Tufts University collections or included in the Brown University Paleobotanical Collections (and possibly relocated to the University of Philadelphia) were also unsuccessful.

Until now, no additional paleobotanical collections have been assembled with the aim of establishing the age of the Wamsutta Formation red beds in the Narragansett Basin. However, Oleksyshyn (1976) derived an Asturian age for the Rhode Island Formation based on macroflora from an open-pit quarry; the Rhode Island Formation interfingers with and overlies the Wamsutta Formation. Also, Lyons et al. (1976) recorded a florule from the Upper Pondville Conglomerate, which underlies and interfingers with the Wamsutta Formation, in the adjacent Norfolk Basin; they assigned it a late Duckmantian age.

A summary of the new fossil-plant collections from the lower Wamsutta Formation in the study area is shown in Table 1. Twenty-two plant-fossil taxa are reported. All of the specimens are fragmentary and many are not well preserved, as might be expected from plant fossils from sandstone, red claystone and red shale. It took numerous collecting trips-mainly by the second author-over several years to gather the modest collection of about 1000 specimens, of which approximately 200 are in a good state of preservation.

In addition to reporting new plant fossils from the Wamsutta Formation in the Narragansett Basin, we illustrate each of the plant-fossil taxa recognized in Knox (1944), and re-evaluate his identifications. Lastly, we establish the age of the lower Wamsutta Formation macroflora on the basis of correlations with similar, poorly understood Middle Pennsylvanian macrofloral zones in the Maritime Provinces and western Europe.

\section{GEOLOGICAL CONTEXT}

The Narragansett Basin of Massachusetts and Rhode Island (Fig. 1) is a composite, intermontane rift basin formed from the coalescence of small grabens as Laurentia and the Avalon microcontinent collided during the Paleozoic (Shaler et al. 1899; Mosher 1983). The Basin is primarily infilled
Table 1. Wamsutta taxa systematically arranged, with semiquantitative (not census sampled) occurrence information. VC = Very Common, $\mathbf{C}=$ Common, $\mathbf{R}=$ Rare, $\mathbf{V R}=$ Very Rare.

Order Medullosales

Family Alethopteridaceae

Neuralethopteris schlehanii $\mathbf{C}$

Family Cyclopteridaceae

Laveineopteris cf. loshii VR

Cyclopteris sp. VR

Family Neurodontopteridaceae

Neuropteris cf. obliqua $\mathbf{C}$

Order Lyginopteridales

Family Lyginopteridaceae

Mariopteris sp. VR

Mariopteris sp. sensu lato Zeiller VR

Order Botryopteridales

Family Tedeleaceae

Senftenbergia plumos a C

Order Filicales

Family Filicophyta insertae sedis

Sphenopteris valida $\mathbf{C}$

Order Equisetales

Family Calamitaceae

Calamites suckowii VC

Annularia asteris VC

Annularia cf. microphylla $\mathbf{R}$

Annularia radiata $\mathbf{C}$

Asterophyllites charaeformis $\mathbf{C}$

Asterophyllites grandis C

Asterophyllites lindleyanus $\mathbf{C}$

Asterophyllites longifolius $\mathbf{C}$

Calamostachys sp. VR

Order Bowmanitales

Family Bowmanitaceae

Sphenophyllum cf. cuneifolium VR

Order Cordaitales

Family Cordaitaceae

Cordaites cf. principalis VC

Artisia sp. R

Order Lepidodendrales

Family Sigillariaceae

Sigillaria sp. $\mathbf{R}$

Cyperites sp. C

with terrestrial sedimentary rocks, and depositional environments include alluvial fans, braided and meandering streams, floodplains, swamps, and freshwater ponds (Shaler 


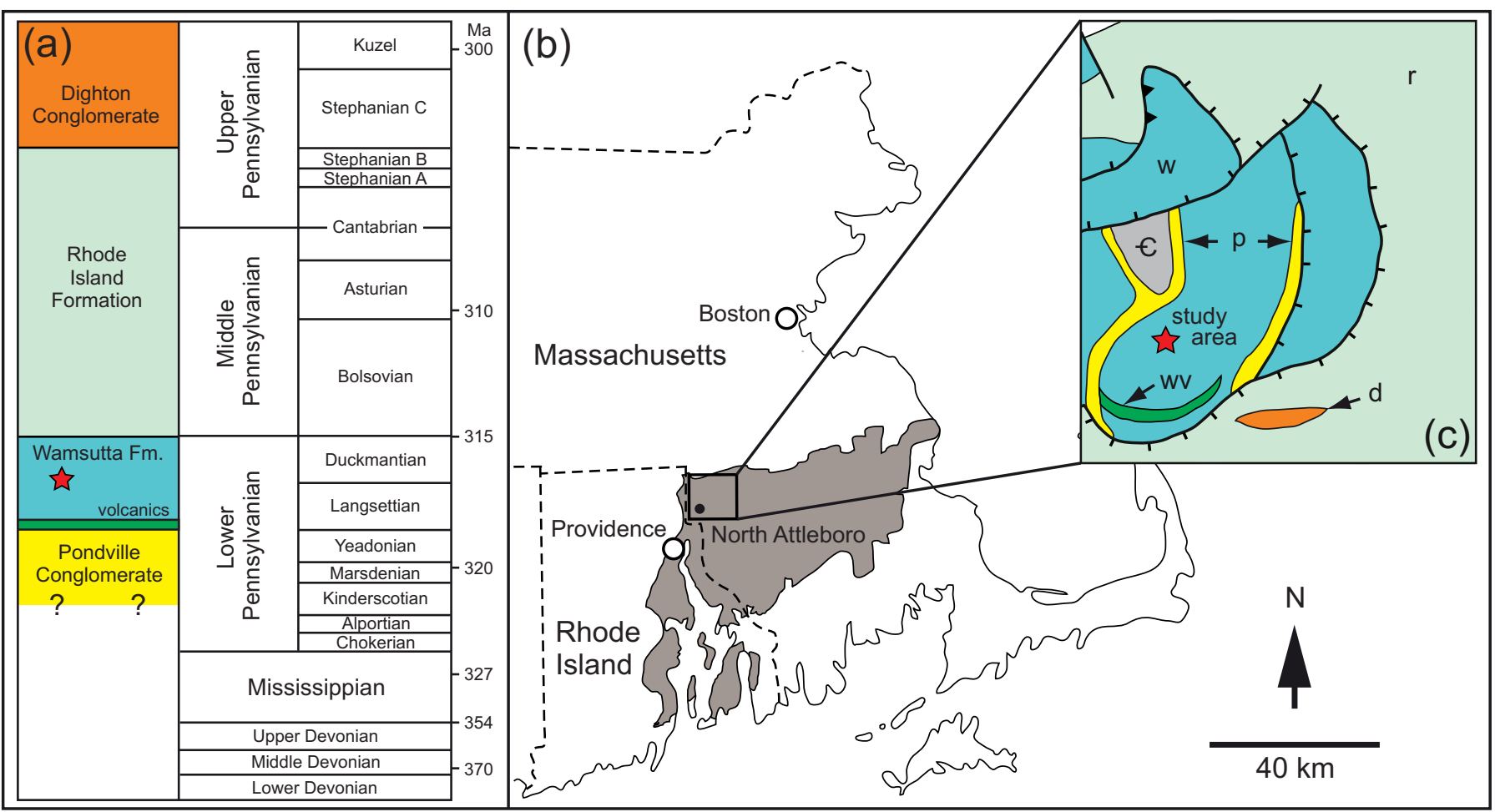

Figure 1. Geologic setting. (a) Generalized stratigraphic column of Narragansett Bay Group. (b) Map of Narragansett Basin in southern New England. (c) Bedrock geology in vicinity of North Attleboro, Massachusetts. Red star in (a) and (c) indicates study location. Abbreviations: $€=$ Cambrian inliers; $w v=$ Wamsutta volcanics; $d$ = Dighton Conglomerate; $\mathrm{p}=$ Pondville Conglomerate; $\mathrm{r}=$ Rhode Island Formation; $\mathbf{w}=$ Wamsutta Formation. Figure courtesy of P.R. Getty. Map modified from Zen et al. (1983) and column modified from Davidov et al. (2010), with data from Maria and Hermes (2001) and Thompson and Hermes (2003).

et al. 1899; Mosher 1983, and references therein; Knecht et al. 2011; Getty et al. 2013). Recent radiometric dating of rhyolite near the base of the Wamsutta Formation (one of the lowermost units of the Basin) suggests that crustal extension began in the Late Devonian, about $373 \mathrm{Ma}$ (Maria and Hermes 2001; Thompson and Hermes 2003). Previously, most authors (e.g., Shaler et al. 1899; Towe 1959; Quinn and Oliver 1962; Skehan et al. 1979; Mosher 1983) had considered basin formation to have begun with the deposition of the Pondville Conglomerate in the Early Pennsylvanian.

The Pondville Conglomerate, the basal unit in the Narragansett Basin, is a $150 \mathrm{~m}$-thick unit of grey to greenish conglomerate containing quartzite, granite and schist clasts up to $60 \mathrm{~cm}$-thick interbedded with red and green slate, arkose, and siltstone (Shaler et al. 1899; Skehan et al. 1979). The conglomerate sometimes grades upward into grey sandstone that may grade into red Wamsutta Formation beds (Skehan et al. 1979) (see below).

Most strata in the Narragansett Basin comprise the Rhode Island Formation, which overlies and interfingers with the Wamsutta Formation. The Rhode Island Formation is almost $3000 \mathrm{~m}$ thick and consist of grey polymictic conglomerate, grey quartz-rich sandstone and siltstone, grey to black shale, and coal seams up to $10 \mathrm{~m}$ thick (Lyons 1977; Skehan et al. 1979; Murray et al. 2004). A rich variety of fossil plants and, to a lesser extent, faunal ichnofossils and insect wings, occur in the formation (Scudder 1893; Oleksyshyn 1976; Sproule and Getty 2012; Getty et al. 2013, 2017). Biostratigraphic analyses of the fossil flora indicate that the age of the Rhode Island Formation ranges from early Bolsovian to Stephanian B or C (Oleksyshyn 1976; Skehan et al. 1979; PCL and RGS unpublished data).

The uppermost lithostratigraphic unit in the Narragansett Basin is the Dighton Conglomerate, which is $300-450 \mathrm{~m}$ thick and correlative to the Purgatory Conglomerate in the southern Narragansett Bay (Skehan et al. 1979; Lynn and Kroll 2006). The Dighton Conglomerate, which extends in age almost up to the Permian, is the highest unit in the Basin (Mosher 1983; Mosher and Rast 1984; Wagner and Lyons 1997; Rich 2006) and is composed of coarse-grained sandstone with quartzite cobbles, some of which display molds of Cambrian brachiopods (Shaler et al. 1899; Skehan et al. 1979).

The Wamsutta Formation red beds overlie the Pondville Conglomerate and are composed of conglomeratic to arkosic sandstone, cross-bedded medium- to fine-grained sandstone, siltstone, and red shales that are approximately $300 \mathrm{~m}$ thick and rare freshwater limestone (Shaler et al. 1899; Mutch 1968). In the Narragansett Basin, the Wamsutta Formation includes a significant number of volcanic 
deposits, and felsic clasts are common in conglomeratic layers (Skehan et al. 1979; see Fig. 2a). Maria and Hermes (2001) and Thompson and Hermes (2003) considered the volcanic rocks to be of Devonian age based on $\mathrm{U}-\mathrm{Pb}$ dating, which suggests that an unconformity is present within the formation. One of us (PCL) has seen that the contact between the volcanic rocks and the overlying portions of the Wamsutta Formation is gradational, and thus we consider the volcanic rocks to be of Pennsylvanian age, like the rest of the formation. The red beds within the Wamsutta Formation, which originated as a series of well-drained alluvial fans, include several horizons with plant fossils. However, deposits with compressed, carbonized (coalified) flora representing anoxic, swampy environments are absent (Shaler et al. 1899; Knox 1944; Lyons and Chase 1976).

The Wamsutta study area, from which the new fossil-plant collections were obtained, comprises several small, closely spaced outcrops on the southern flank of Red Rock Hill in North Attleboro, Massachusetts (Fig. 2b), the type locality of the Wamsutta Formation. The outcrops lie about in the middle of that part of the lower Wamsutta succession exposed locally, and are stratigraphically $100 \mathrm{~m}$ or more above
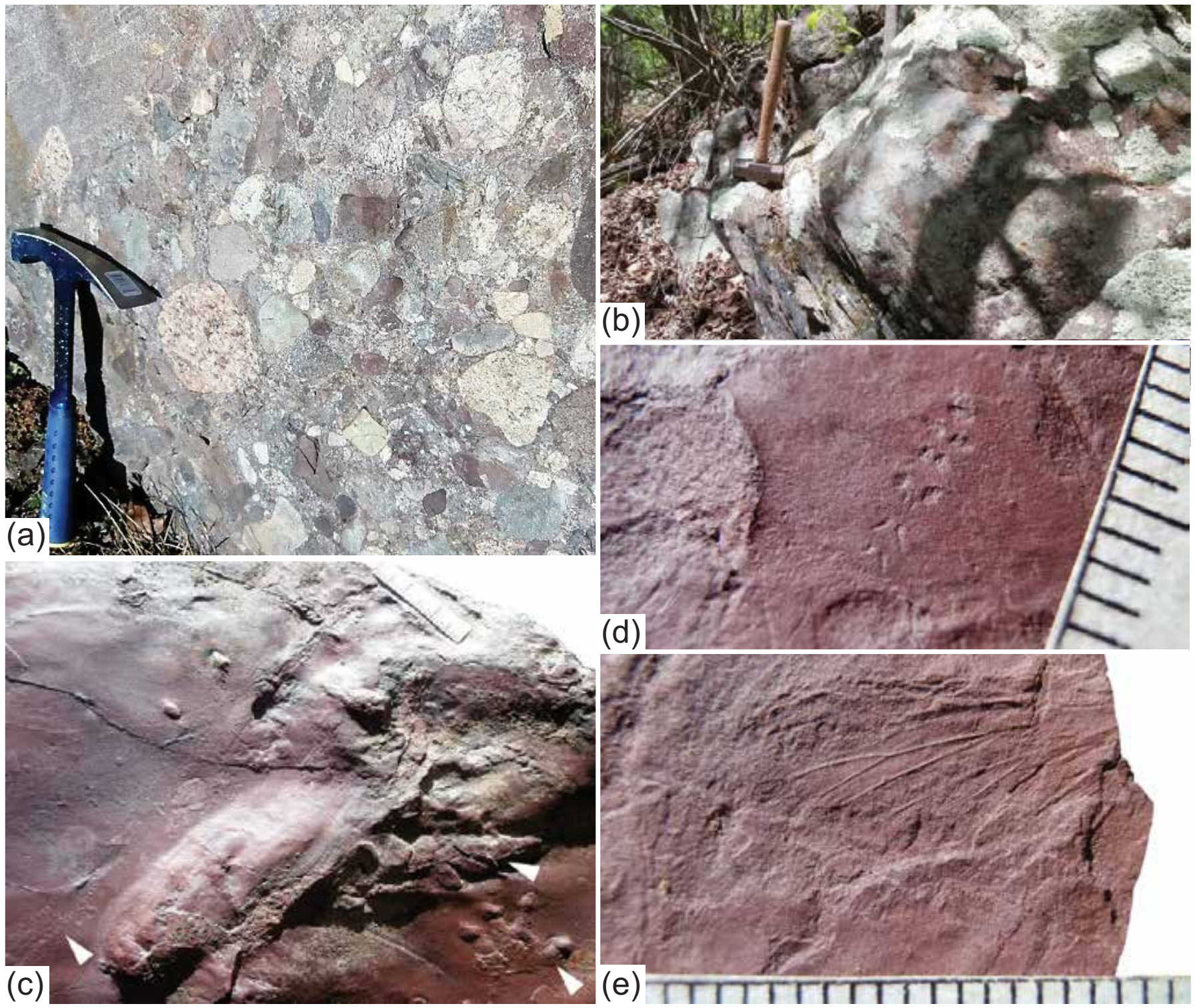

Figure 2. (a) Exposure of the Wamsutta Formation in study area. Note granite (light-colored) and volcanic (dark) clasts in conglomerate with coarse sandstone at upper right. Geologic hammer gives scale. (b) Exposure of Wamsutta Formation in study area. Note steeply dipping, laminated sandstone (lower left centre) overlain by thick conglomerate. Height of hand sledge is $40 \mathrm{~cm}$. (c) Amphibian footprints with biserial Diplichnites trackway (arrowed; lower left). Note fossil seed fern (arrowed; Neuropteris?) just above footprint (arrowed) at lower right. Collection of RGS. Scale equals $3 \mathrm{~cm}$. (d) Tonganoxichnus sp., an archaeognathan insect ventral impression. Collection of RGS. Scale in millimetres. (e) Neopteran insect wing (Order Blattaria?). Collection of RGS. Scale in millimetres. 
outcrops of the basal felsite flows (Knox 1944). The northeasterly to northwesterly trending strata are capped by laterally continuous conglomerate with coarse-grained, poorly sorted, cross-bedded sandstone $3 \mathrm{~m}$ or more thick. Beds dip east-northeast at about 60 degrees in the northwestern part of the study area, and northwest at 35 degrees in the southeastern margin.

Underlying the study area's coarse strata are thin sequences of ripple-laminated, medium- to fine-grained sandstone beds, graded in cross-section and draped with red shale, that indicate recurrent flooding (and drainage) by shallow streams on a low-relief floodplain. Plant detritus, especially cordaitalean leaves, sphenophyte stems, and pteridosperm pinnae, are sometimes preserved on bedding-plane surfaces, as are sedimentary structures including raindrop imprints, asymmetric current ripples, wrinkled mud, tool marks, pressure casts ("mud bubbles"), gas-escape structures, and occasional desiccation cracks. Entombed stem casts with whorled leaves and/or plant stem cross-sections with pinwheeled eddy patterns frequently poke through these substrates, indicating the presence of upright sphenophytes and other plants in growth position. Red shale predominates in a few areas and forms distinct plant-fossil facies with thicknesses of up to approximately $1 \mathrm{~m}$. Accompanying the fossil plants are well-preserved ichnofossils, such as numerous footprints of reptiles and basal amphibians (Fig. 2c), plentiful biserial Diplichnites trackways (referred to myriapods) (Fig. 2c), other invertebrate traces including four ephemeropteran and 11 archaeognathan insect ventral body impressions (Fig. 2d), and a rare neopteran (order Blattaria?) insect wing (Fig. 2e). Thin lithified paleosols lacking in fossil macroflora may underlie and/or overlie the fossiliferous fine-grained sandstone and shale horizons. All told, the Wamsutta Formation study area displays many of the characteristics of a moist, sub-humid (seasonally dry to seasonally wet), clastic wetland habitat on an alluvial fan landscape lush with tropical forestation (see Bashforth et al. 2014).

\section{MATERIAL AND METHODS}

Simple hand sledges and pry bars were used to loosen and extricate specimens from two low-lying, unexploited, well-indurated ledges exposed in the study area on Red Rock Hill $\left(41.937^{\circ} \mathrm{N}, 71.353^{\circ} \mathrm{W} ; 41.939^{\circ} \mathrm{N}, 71.354^{\circ} \mathrm{W}\right)$; the latter ledge produced all of the insect fossils. Knox's (1944) fossil-flora locality, a road cut along the west side of U.S. Route 1 near the Attleboro-North Attleboro town line, is about $250 \mathrm{~m}$ to the southeast of the study area. Approximately $100 \mathrm{~m}$ north of the study area, fossil tetrapod footprints have been reported (Willard and Cleaves 1930; Knecht and Benner 2008) along with an ephemeropteran insect impression, several archaeognathan insect impressions, and at least two insect wings (Knecht et al. 2011; Benner et al. 2015).

The new collection of the lower Wamsutta Formation macroflora is reposited in the Harvard University Paleobotanical Collections (HUPC) in Cambridge, Massachusetts.
HUPC accession numbers have been assigned that refer to the slabs on which the specimens are preserved. Images of key and/or uncertain plant species were sent to paleobotanists for their opinions on identification. Specimens were photographed in natural sunlight with an Olympus VR 350 16-megapixel camera. Measurements were made directly from the specimens and are given in standard international (SI) metric system units.

\section{SYSTEMATIC PALEONTOLOGY}

\author{
Order Medullosales Corsin 1960 \\ Family Alethopteridaceae (Lesquereux 1884) Corsin 1960 \\ emend. Anderson et al. 2007
}

Genus Neuralethopteris Cremer 1893

\section{Neuralethopteris schlehanii (Stur 1877) Cremer 1893 \\ (Figs. 3a-b)}

Remarks. Pinnules are usually tongue-shaped with a rounded apex, and have a cordate base in some parts, or are stalked or attached to the base in other areas, but are not decurrent or confluent as in alethopterids. A strong midvein nearly reaches the pinnule apex, and lateral veins extend at an acute angle, forking two or three times to meet the margin almost perpendicularly (Goubet et al. 2000), as opposed to meeting the margin obliquely as in neuropterids such as Neuropteris obliqua and Laveineopteris loshii. The rachis is striated longitudinally (Bell 1944).

Neuralethopteris schlehanii is a common component of Namurian and Langsettian tropical rainforest florules in Europe, and is a key arborescent species, perhaps $3 \mathrm{~m}$ tall, in similar Langsettian-age florules from the Cumberland Group of the Maritime Provinces (Bell 1944; Falcon-Lang et al. 2006). Neuralethopteris schlehanii has been seldom recorded in the United States (Goubet et al. 2000), and is recorded herein for the first time in the Narragansett Basin. Sizable frond fragments of Neuralethopteris schlehanii were found in the lower Wamsutta littering bedding planes of shallow, low-energy, sand-bed channels and low-relief fluvial embankments, in association with Cordaites cf. principalis, Laveineopteris cf. loshii, Calamites suckowii, and Asterophyllites lindleyanus. Neuralethopteris schlehanii became abruptly extinct in western Europe at the end of the Langsettian and is, therefore, very useful biostratigraphically (Goubet et al. 2000).

\section{Family Cyclopteridaceae Corsin ex Wagner 1964}

Genus Laveineopteris Cleal et al. 1990

Laveineopteris cf. loshii (Brongniart 1831) Cleal et al. 1990 (Figs. 3c-d)

Remarks. J.-P. Laveine (personal communication) was 

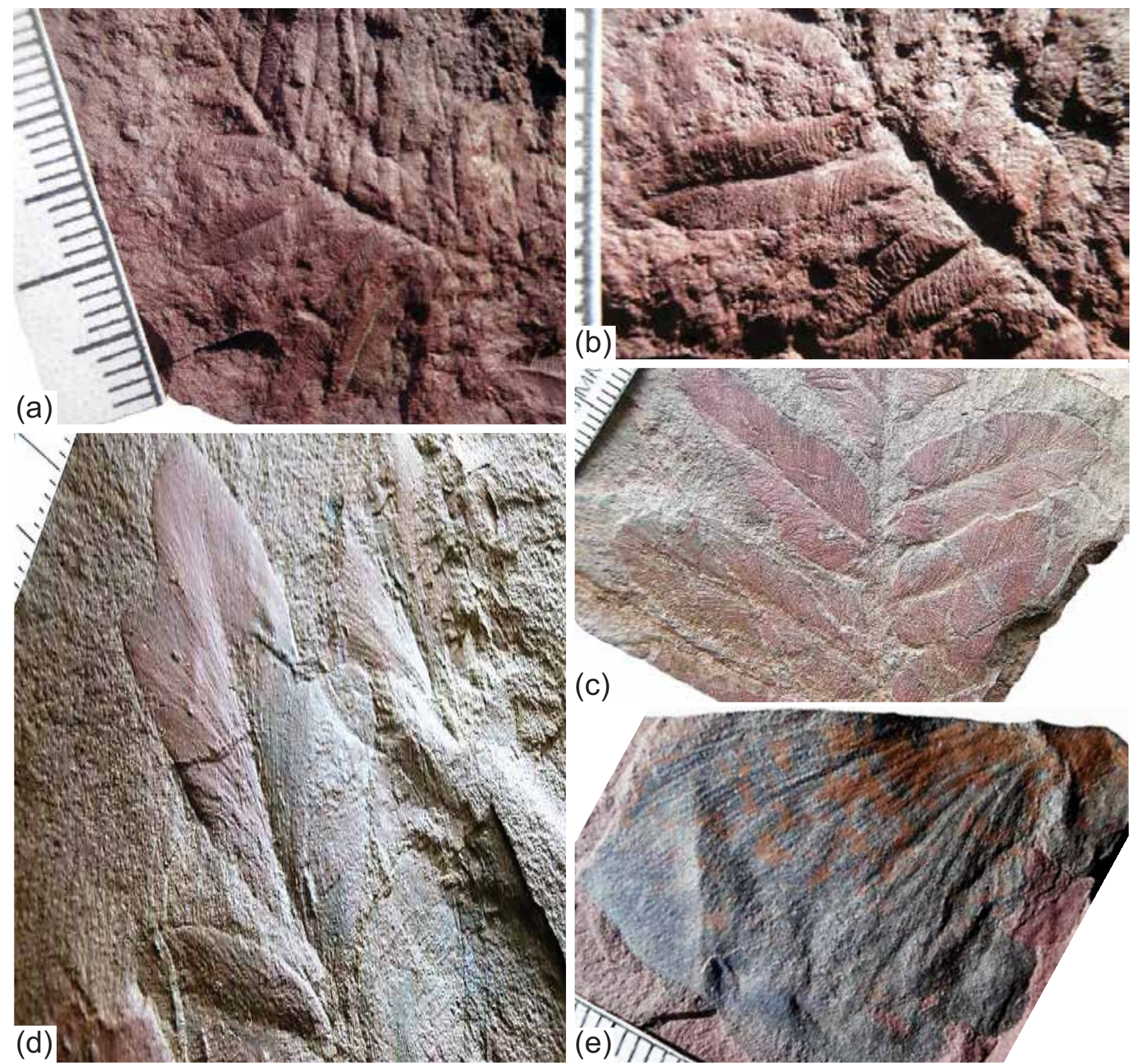

(c)

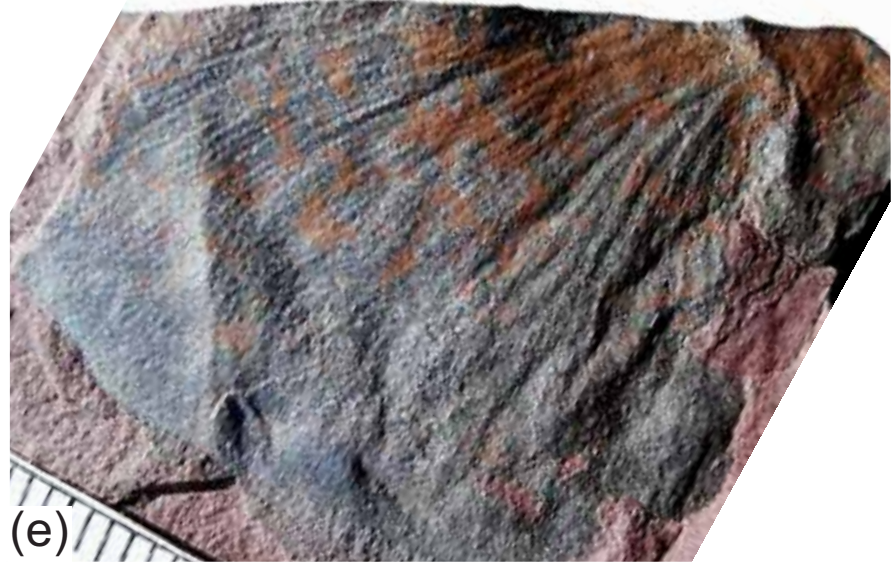

Figure 3. (a) HUPC No. 64,894, Neuralethopteris schlehanii. Specimen identified by Jean-Pierre Laveine, Lille, France. (b) Close-up of HUPC 64894, Neuralethopteris schlehanii. Note alethopteroid venation and non-decurrent, non-confluent pinnules attached to rachis. (c) HUPC No. 64,846A, Laveineopteris cf. loshii. Note well-preserved venation. Some pinnules appear to taper near the base. Specimen identified by Jean-Pierre Laveine, Lille, France. (d) HUPC No. 64,882, Laveineopteris cf. loshii. Note large deltoidal terminal pinnule and subjacent pinnules. Specimen identified by Jean-Pierre Laveine, Lille, France.(e) HUPC No. 64,870, Cyclopteris sp., incomplete orbicular shade leaf. All scales in millimetres.

uncertain of the species designation; consequently, we only tentatively assign the Wamsutta specimens to Laveineopteris loshii. The median vein is strong; the lateral veins arise acutely, are dense, bifurcate acutely several times, and meet the margin at oblique angles. The terminal pinnule is deltoid, and subjacent pinnules may be broadly attached (Cleal and Shute 2003). Large fronds grew on arborescent plants that may have approached the local forest canopy in height.
Associated cyclopterid shade leaves may be preserved nearby (Cleal and Shute 2003).

Although well known throughout the Duckmantian substage, Laveineopteris loshii first appears and becomes common in the wetland deposits of middle Langsettian tropical rain forests. As a result, Cleal (1991) proposed a biostratigraphically useful floral subzone, the "Laveineopteris loshii Subzone", in the Langsettian substage, based in part on this 
initial appearance (see also Cleal and Thomas 1994).

In the Wamsutta Formation, sizable frond fragments of Laveineopteris cf. loshii (up to at least $20 \mathrm{~cm}$ long) are occasionally encountered as well-preserved parautochthonous detritus on the bedding planes of shallow-channel sandstones and adjacent floodplain shales. Large, broad pinnae with full-bodied, ovate pinnules distinguish Laveineopteris loshii from the smaller pinnae and lanceolate/linguate pinnules of Neuropteris obliqua and Neuralethopteris schlehanii. The absence of lobed pinnae distinguishes Laveineopteris loshii from species of Mariopteris.

\section{Genus Cyclopteris Brongniart 1828a}

\section{Cyclopteris spp.}

(Fig. 3e)

Remarks. Isolated, orbicular and kidney-shaped leaves that display radiating venation are characteristic of the fossilgenus Cyclopteris (Janssen 1965; Cleal and Shute 2003). Cyclopteris pinnules were attached to those parts of adult trees below the canopy, which were probably shade leaves. Sun leaves, such as Laveineopteris loshii fronds, may have grown high above on the same tree (Cleal and Shute 2003). The iso-lated and detached nature of Cyclopteris pinnules, combined with characteristic radiating venation, easily distinguishes them in the field.

Only one example of Cyclopteris has been found in the Wamsutta Formation red beds. By contrast, the associated sun leaves, Laveineopteris cf. loshii pinnae (Figs. 3c-d), have been found as preserved litter on bedding planes in several fluvial wetland horizons.

\section{Family Neurodontopteridaceae Laveine 1966}

Genus Neuropteris (Brongniart 1822) Sternberg 1825 emend. Cleal et al. 1990

\section{Neuropteris obliqua (Brongniart 1833-1834) Zeiller 1886} (Figs. 4a-b)

Remarks. This species of arborescent seed fern is characterized by mixoneuroid venation, with the lateral pinnules near the apices of the pinnae united to the rachis, and a small, lanceolate terminal pinnule (Bell 1944; Darrah 1969; Josten 1991). Pinnae may be highly variable in morphology (Darrah 1969).

Neuropteris obliqua is distinguished from species of Mariopteris in not having lobed pinnules, from Neuropteris schlehanii by its shorter midvein and acutely rising lateral veins, and from Laveineopteris loshii by its smaller, more lanceolate terminal pinnule and less robust subjacent pinnules.
Neuropteris obliqua is most frequently encountered in late Langsettian and early Duckmantian rainforest florules worldwide, such as those found in the Iberian Peninsula of western Europe (Cleal 2005; Wagner and Álvarez-Vázquez 2010), and in the Cumberland Group in the Maritime Provinces (Bell 1944; Falcon-Lang et al. 2006; Falcon-Lang et al. 2010; Bashforth et al. 2014). Neuropteris obliqua is the dominant seed fern found in the Wamsutta Formation in the study area. It was approximately 3-5 m tall and usually preserved as parautochthanous (full or partial) lone pinnae, isolated pinnules, or rarely as multiple attached pinnae compressed/adpressed upon bedding planes of mudstone and shale representing low-energy channel, proximal flood-plain, and soggy non-swamp settings.

\section{Order Lyginopteridales (Corsin 1960) Havlena in Dvořák and Růžička 1961 \\ Family Lyginopteridaceae Potonié 1900 emend. Anderson et al. 2007}

Genus Mariopteris Zeiller 1879

\section{Mariopteris sp.}

(Fig. 4c)

Remarks. Pinnae from this genus of arborescent seed fern are characterized by pinnules, entire or lobed, with broad bases. Pinnules may exhibit a thick, leathery or coriaceous appearance (Janssen 1965; Darrah 1969). Lobed pinnules that lack a conspicuous midvein distinguish Mariopteris sp. from Neuropteris obliqua and Neuralethopteris schlehanii. Generally, Mariopteris sp. pinnules are less segmented than those of Sphenopteris, and their venation may be more coarse and conspicuous (Janssen 1965).

Mariopteris sp. ranges through the Westphalian, and is represented in the new Wamsutta collections by a single specimen, collected in a sandstone reflecting a shallowchannel setting along with specimens of Laveineopteris cf. loshii, Cordaites cf. principalis and Neuropteris obliqua.

\section{Mariopteris sp. sensu lato Zeiller 1879}

(Fig. 4d)

Remarks. This form has similar characteristics to the above form described as Mariopteris sp. Pecopteroid or (less commonly) sphenopteroid sub-triangular pinnules are attached for the full width of the base, are more or less united, and are often decurrent (Darrah 1969). The largest pinnules may display a cordate, sessile base (Bell 1944).

Only two specimens have been collected by the authors to date (Figs. 4c-d), both retrieved on bedding planes of shale-draped sandstone deposited in shallow, low-energy channels. 

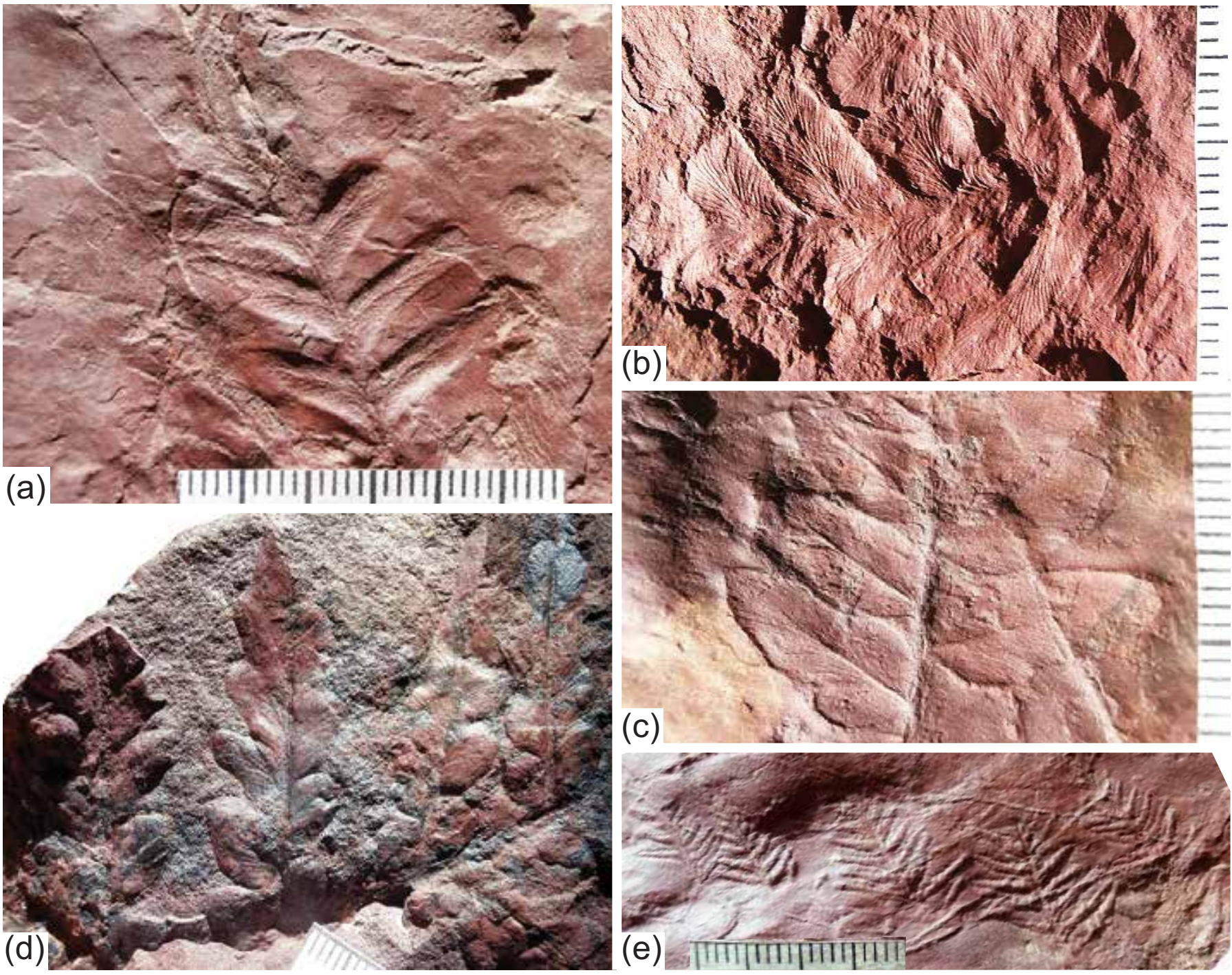

Figure 4. (a) HUPC No. 64,851, Neuropteris obliqua. Note mixoneuroid venation and small, lanceolate terminal pinnule. Scale equals $3 \mathrm{~cm}$. (b) HUPC No. 64,875A, Neuropteris obliqua. Superb mixoneuroid venation is displayed. Scale in millimetres. (c) HUPC No. 64,867, Mariopteris sp. The largest lobed pinnule is $13 \mathrm{~mm}$ long. Scale in millimetres. (d) HUPC No. 64,858, Mariopteris sp. sensu lato Zeiller. Specimen identified by Jean-Pierre Laveine, Lille, France. Scale in millimetres. (e) HUPC No. 64,853, Senftenbergia plumosa. Specimens identified by Robert H. Wagner, Córdoba, Spain via photograph. Scale in millimetres.

Order Botryopteridales Meyen 1987

Family Tedeleaceae Eggert and Taylor 1966

Genus Senftenbergia Corda 1845

\section{Senftenbergia plumosa (Artis 1825) Stur 1885 emend. Bek and Pšenička 2001}

(Fig. 4e)

Remarks. Pinnae are small, and so venation may be difficult to discern, but the margins of pinnules are crenulated. The midvein is slightly flexuous, a branch entering a lobe divides once, with the upper arm perhaps dividing again (Bell 1944). The small size of the lanceolate pinnae and the very small, narrow, crenulated pinnules distinguish it from other fern-like taxa in the Wamsutta Formation.

Senftenbergia plumosa was an abundant Late Carboniferous fern that historically had long been assigned to family Pecopterideae, as Pecopteris plumosa. Only recently has Senftenbergia plumosa been recognized as a representative of the Late Carboniferous fern family Tedeleaceae (Pšenička and Bek 2001).

According to some authors (e.g., Brousmiche Delcambre et al. 1998), Senftenbergia plumosa ranged throughout the Carboniferous, but Cleal (2005) gave it an early Langsettian to middle Bolsovian age. Senftenbergia plumosa is abundant and widespread in the Cumberland Group of the Maritime Provinces, and is also a common representative of the 
arborescent wetland macroflora in the lower Wamsutta Formation in the study area. Although one frond fragment has been collected, most Wamsutta specimens of this taxon are found as detached parautochthonous pinnae in fine-grained sandstones representing shallow sand-bed channels and their proximal low-relief embankments and floodplains.

\section{Order Filicales Engler \& Prantl 1902 \\ Family Filicophyta incertae sedis}

\section{Genus Sphenopteris (Brongniart 1822) Sternberg 1825}

\section{Sphenopteris valida Dawson 1868}

(Fig. 5a)

Remarks. Lacy lobate pinnules branch off on each side and bifurcate at acute angles, are alternate, petiolate and obtuse, and may taper gradually to a point (Janssen 1965; Josten 1991). A single vein enters the pinnule from the rachis, forking several times such that one or two veinlets enter each lobe of the distal margin (Janssen 1965). Sphenopteris valida differs from Neuropteris obliqua, Laveineopteris loshii, and Neuralethopteris schlehanii in having lobate pinnules without a prominent midvein, and from Senftenbergia plumosa in having lobate, non-crenulated pinnules. Mariopteris sp. does not have petiolate pinnules.

Biostratigraphic ranges given by authors for this species vary, but Wagner and Álvarez-Vázquez (2010) list Sphenopteris valida (= Sphenopteris artemisiaefolioides; see Stopes 1914; Bell 1944) as ranging primarily from Langsettian to Duckmantian. Reported previously by Knox (1944) and found typically in the Wamsutta Formation as full or partial parautochthonous pinnae, Sphenopteris valida is a common, shrub-sized form preserved in fine-grained strata reflecting shallow, sand-bed channels and their proximal floodplains.

\section{Order Equisetales Du Mortier 1829 \\ Family Calamitaceae Unger 1840}

Genus Calamites Brongniart 1828b

Calamites suckowii Brongniart 1828b (Fig. 5b)

Remarks. Calamites suckowii is best known as limb casts displaying coarse ribs with bluntly obtuse ends that alternate at the nodes (Janssen 1965). Internodes are not constricted and their length is less than the limb diameter. Verticils of branch scars are present at varying intervals (Bell 1944). Ribs may be flattened, longitudinally striated; large leaf scars are oval to circular at the upper ends of ribs (Darrah 1969). Calamites suckowii is distinguished from other calamitean taxa by its short internode distance, and by its coarse, blunt ribs alternating at the nodes.

Calamites suckowii grew in groves to the height and dimensions of a small tree, and was an abundant (often the dominant) sphenophyte in Lower and Middle Pennsylvanian macrofloras, including those of the Iberian Peninsula, the Cumberland Group, and the Wamsutta Formation. Casts of Calamites suckowii in the Wamsutta Formation have been found oriented perpendicular to bedding planes in fluvial levee-complex sandstones (indicating rapid in situ burial), as well as lying horizontally upon bedding plane surfaces with other plant litter in channel strata. Occasionally, these casts are transversely imprinted with needle-like leaves of Asterophyllites longifolius.

\section{Genus Annularia Sternberg 1821}

\section{Annularia asteris Bell 1944}

(Fig. 5c)

Remarks. This seldom accurately reported species is characterized by very small, rather stiff, straight-sided leaflets 2 to $4.5 \mathrm{~mm}$ long with acuminate tips. Up to ten isophyllous, narrow leaflets only slightly constricted at the base may comprise a verticil (Bell 1944; Álvarez-Vázquez and Wagner 2017). Ultimate branches are very slender (Bell 1944); two sizes of leaflets may be displayed on branches of the same plant (Abbott 1958). Annularia asteris is distinguished from other whorled taxa by being the most diminutive; its stiff, straight leaves separate it from the slighter longer, sickleshaped leaves of Annularia microphylla.

Annularia asteris is very common in the Wamsutta Formation in the study area, where it probably grew as luxuriant groves of short groundcover in abandoned channels, on flanks of channels, and/or as rapid recovery growth on proximal floodplains of low-energy streams. Annularia asteris is sometimes associated with Asterophyllites charaeformis (Álvarez-Vázquez and Wagner 2017) and, interestingly, a similar association is noted in two new Wamsutta specimens. Reportedly ranging from Kinderscoutian to Bolsovian in western Europe (Wagner and Álvarez-Vázquez 2010; Álvarez-Vázquez and Wagner 2017), Annularia asteris is reported herein for the first time in the Narragansett Basin.

\section{Annularia cf. microphylla Sauveur 1848}

(Fig. 5d)

Remarks. Annularia microphylla is marked by longitudinally striate ultimate axes, with anisophyllous verticils displaying 12-16 small, sickle-shaped leaflets 5-6 mm in length. The taxon is only slightly larger in size than Annularia asteris, but Annularia microphylla may also be distinguished from Annularia asteris by its sickle-shaped leaflets with characteristic thick, vaulted laminae (Álvarez-Vázquez and Wagner 2017). The Wamsutta specimens are only tentatively assigned to this species due to their poor preservation.

The species has not been recorded commonly in Europe or the Maritime Provinces, but Wagner and Álvarez-Vázquez (2010) and Álvarez-Vázquez and Wagner (2017) reported it from Langsettian to lower Duckmantian strata. Annularia cf. microphylla is also an uncommon species in the 

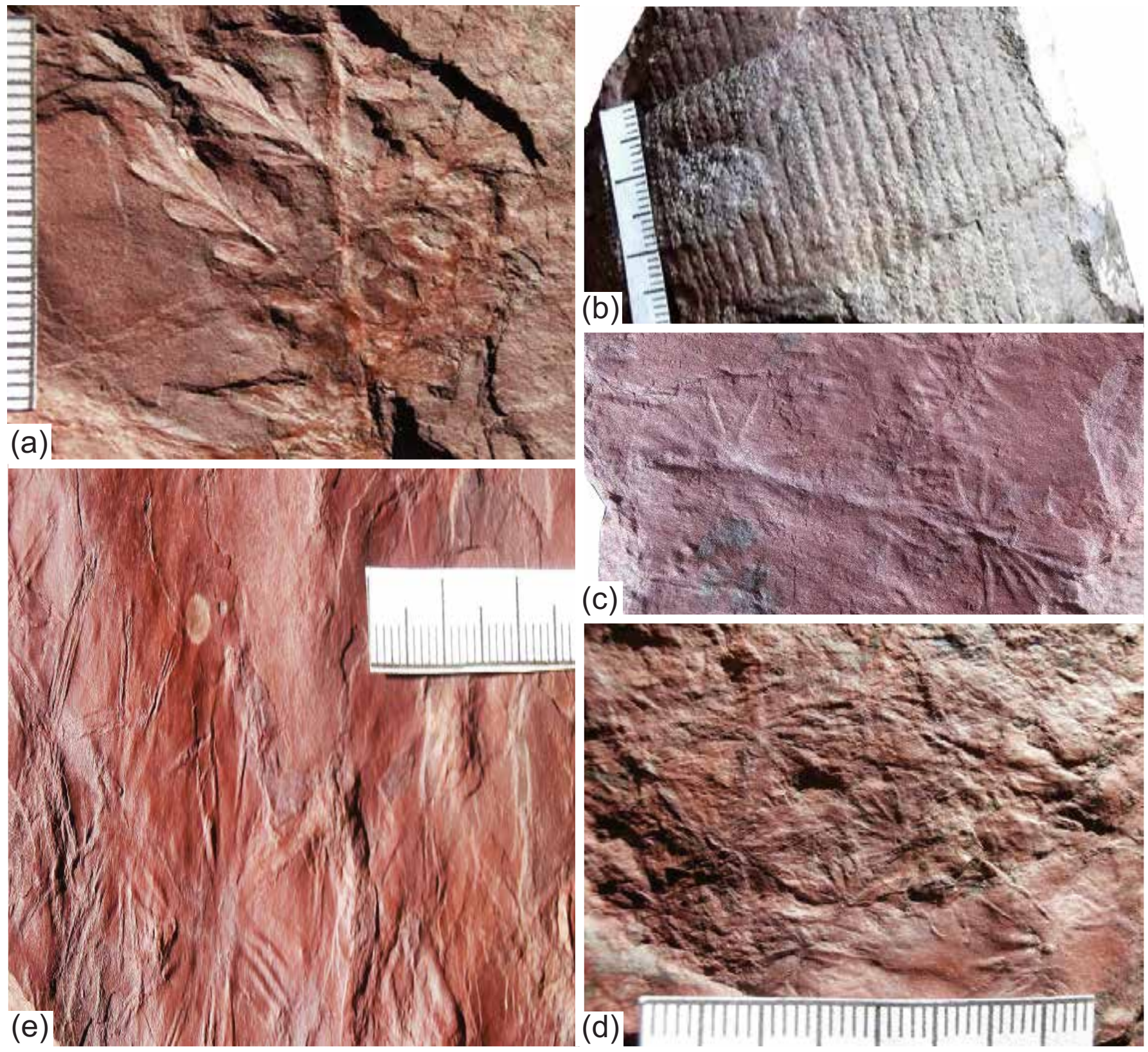

Figure 5. (a) HUPC No. 64,893A, Sphenopteris valida. Elongate-ovate pinnules are characteristic. Scale equals $3 \mathrm{~cm}$. (b) HUPC No. 64,872, Calamites suckowii. Internodes shorter than long and coarse ribs alternate at nodes. Scale equals $3 \mathrm{~cm}$. (c) HUPC No. 64,863B, Annularia asteris showing two sizes of very small, rigid leaflet. Scale equals $3 \mathrm{~cm}$. (d) HUPC No. 64,839, Annularia cf. microphylla. Whorled leaflets are 5-6 mm in length. Scale equals $8 \mathrm{~cm}$. (e) HUPC No. 64856A, Annularia radiata. Leaflets are linear lanceolate with acute apices. Scale in millimetres.

Wamsutta Formation in the study area, but like Annularia asteris probably grew as low shrubs along shallow stream embankments and proximal low-relief floodplains. This is the first record of specimens associated with Annularia microphylla in the Narragansett Basin.

Annularia radiata (Brongniart 1822) Sternberg 1825 (Fig. 5e)

Remarks. Linear lanceolateleaves 11-24 mm in length, 12-16 per verticil with an acute apex characterize this species (Álvarez-Vázquez and Wagner 2017). Isophyllous whorls are spread out on the substrate but do not overlap. Annularia radiata is sometimes confused with Annularia stellata, but is easily distinguished, since the latter species displays distinctly larger anisophyllous whorls of leaves (Abbott 1958; Álvarez-Vázquez and Wagner 2017).

Annularia radiata occurs most often in upper Langsettian and Duckmantian strata (Álvarez-Vázquez and Wagner 2017). In the Wamsutta Formation, sizable parauthochton- 
ous groups of whorled leaves sometimes occur on claydraped channel-sandstone substrates, though two- or three-whorled branch fragments are more common. Workers in the Maritime Provinces and in the Narragansett Basin area (mis)applied the synonym Annularia acicularis to specimens of Annularia radiata, or to specimens too fragmentary (e.g., Oleksyshyn 1976, p. 156, figs. 7B-7D) for precise identification (Álvarez-Vázquez and Wagner 2017). Perhaps this explains why Annularia radiata has not been reported previously in the Narragansett Basin.

\section{Genus Asterophyllites Brongniart 1822}

\section{Asterophyllites charaeformis (Sternberg 1825) Göppert 1844}

(Fig. 6a)

Remarks. Verticils with up to 10 hook-shaped, pointed leaves $2-3 \mathrm{~mm}$ in length (as long as, or slightly longer than, the internodes), and the compact nature of the shoot combine to make this smallest Asterophyllites species distinctive. Axes are slender and can be striate vertically (Bell 1944; Álvarez-Vázquez and Wagner 2017). The sickle-shaped leaves of Asterophyllites grandis are somewhat larger than those of Asterophyllites charaeformis, and distinguish the two species.

In the macrofloras of western Europe, the Iberian Peninsula, and the Cumberland Group of the Maritime Provinces, Asterophyllites charaeformis is recorded as ranging from late Namurian to Bolsovian (Wagner and Álvarez-Vázquez 2010; Álvarez-Vázquez and Wagner 2017). Asterophyllites charaeformis is a fairly common taxon in the Wamsutta Formation, and likely grew as diminutive groundcover in abandoned low-energy channels, and on low-relief floodplains and interfluves. The close resemblance of two of this study's specimens to Matthew's (1906) specimen, with Annularia asteris nearby, is notable (see Álvarez-Vázquez and Wagner 2017, fig. 13).

\section{Asterophyllites grandis (Sternberg 1825) Geinitz 1855} (Fig. 6b)

Remarks. Longitudinally striate axes with internodes $2.5-4$ $\mathrm{mm}$ long characterize this species. Curved, sickle-shaped leaves $4-6 \mathrm{~mm}$ in length are distinctive and overlap slightly at successive whorls (Álvarez-Vázquez and Wagner 2017). Commonly, only two opposite, uninerved leaflets in a verticil are preserved (Bell 1944). Here recorded for the first time in the Narragansett Basin, Asterophyllites grandis is noticeably larger and more robust than Asterophyllites charaeformis (Abbott 1958), with which it may sometimes be confused. Asterophyllites grandis occurs in upper Namurian to upper Bolsovian strata in western Europe and the Maritime Provinces (Álvarez-Vázquez and Wagner 2017). Numerous specimens of Asterophyllites grandis have been collected by the authors in the Wamsutta study area, and apparently represent the foliage of a shrub- or small tree-like sphenophyte inhabiting shallow stream embankments and/or their proximal floodplains.

\section{Asterophyllites lindleyanus Göppert 1848}

(Fig. 6c)

Remarks. Up to 16 linear-lanceolate, whorled leaves 10 $14 \mathrm{~mm}$ long per verticil are characteristic of this taxon. Asterophyllites lindleyanus closely resembles Asterophyllites equisetiformis, and the two species can be confused, but the latter's leaves are often more delicate and thread-like (ÁlvarezVázquez and Wagner 2017). The leaves of Asterophyllites grandis are shorter than those of Asterophyllites lindleyanus, with a smaller length to width ratio, whereas the leaves of Asterophyllites longifolius are twice as long as those of Asterophyllites lindleyanus.

Asterophyllites lindleyanus is common throughout the Wamsutta Formation in the study area, as well as in the Cumberland Group in the Maritime Provinces (ÁlvarezVázquez and Wagner 2017). Asterophyllites lindleyanus seems to have flourished in or near narrow channel margins and levees, as many (parautochthonous) specimens have been recovered by the authors in sandy streambed horizons. This is the first report of Asterophyllites lindleyanus in the Narragansett Basin.

\section{Asterophyllites longifolius (Sternberg 1825) Brongniart 1828a}

(Fig. 6d)

Remarks. This long-ranging late Namurian to Stephanian species is readily recognized by its $25-40 \mathrm{~mm}$ long leaves, which may overlap several verticils. Each verticil may comprise up to 20 leaves. Usually, leaves of Asterophyllites longifolius are thin and filiform (Álvarez-Vázquez and Wagner 2017), but may be occasionally sickle-shaped.

Isolated leaves of Asterophyllites longifolius are fairly common in the Wamsutta Formation in the study area, but are difficult to notice among the stems, tendrils, and vegetative litter on fossiliferous substrates. Elongate, needle-like leaves of Asterophyllites longifolius are sometimes imprinted into limb casts of Calamites suckowii that are rarely encountered lying flat on stream channel beds and flanks.

\section{Calamostachys Schimper 1869}

\section{Genus Calamostachys sp.}

(Fig. 6e)

Remarks. Calamostachys is the cone-shaped fructification of calamiteans (Josten 1991), which range widely throughout Pennsylvanian time. In contrast to Lepidostrobus sp., horizontally arranged, short and stiff bracts may present a distinctive saw-toothed appearance across the cone of Calamostachys (Bell 1944).

Calamostachys is fairly common in the study area, but is 

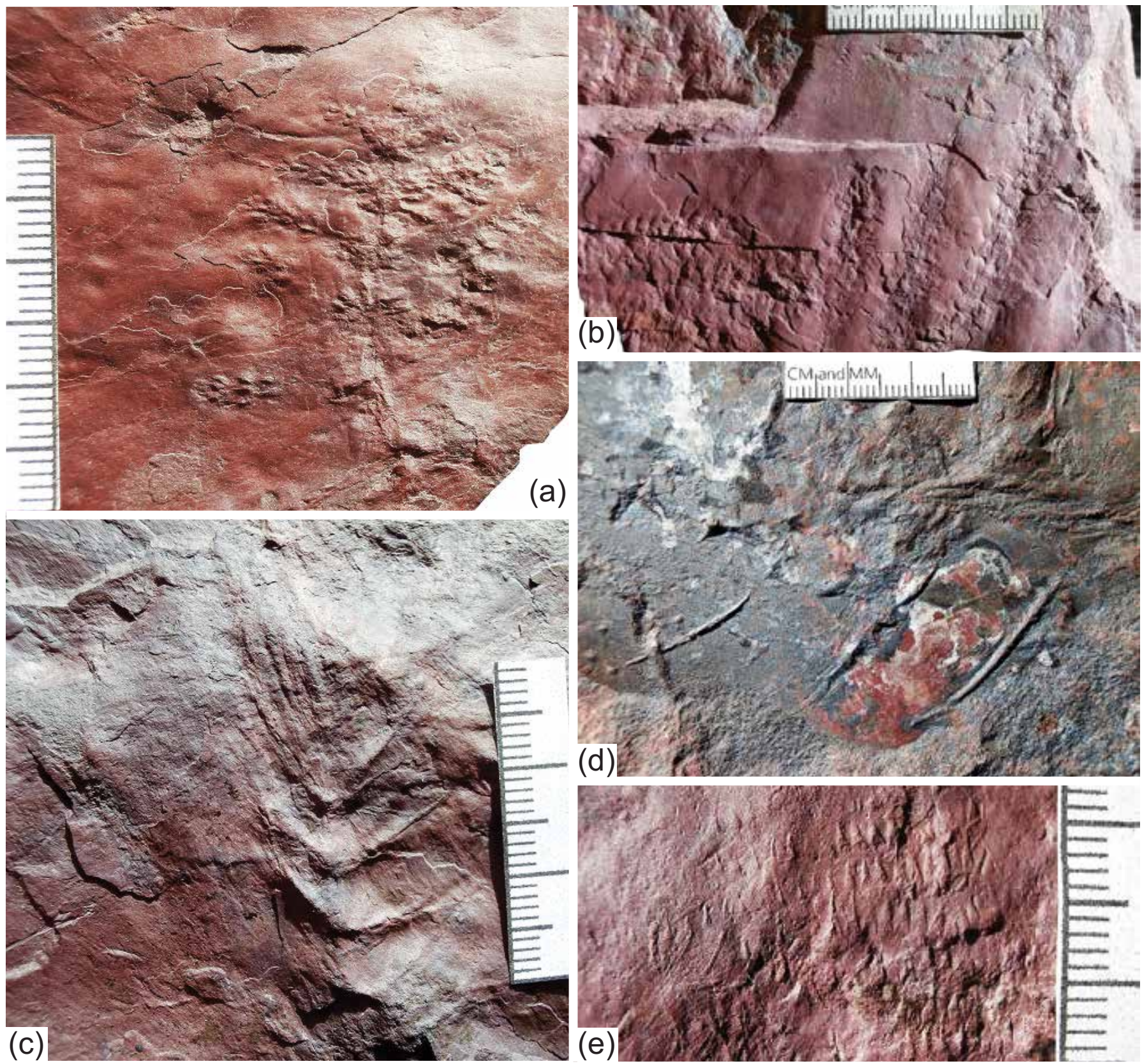

Figure 6. (a) HUPC No. 64,898, Asterophyllites charaeformis. Very small cupped leaflets are typical of this species. Scale equals $3 \mathrm{~cm}$. (b) HUPC No. 64,859, Asterophyllites grandis. Four specimens on one slab. Scale equals $3 \mathrm{~cm}$. (c) HUPC No. 64,897, Asterophyllites lindleyanus. 10-14 mm leaflets are characteristic. Scale equals $3 \mathrm{~cm}$. (d) HUPC No. 64,849, Asterophyllites longifolius. Elongate leaves $25-40 \mathrm{~mm}$ in length distinguish species. Scale equals $3 \mathrm{~cm}$. (e) HUPC No. 64,899A, Calamostachys sp. Note short, rigid bracts arranged horizontally. Scale in millimetres.

generally too poorly preserved to observe details that would determine assignment to a species. Like the fragments of the parent calamitean plants, Calamostachys cones are encountered in the Wamsutta Formation as parautochthonous litter on fine-grained bedding planes of strata that represent abandoned channels and adjacent floodplains.
Order Bowmanitales Meyen 1978

Family Bowmanitaceae Meyen 1978

Genus Sphenophyllum Brongniart 1822

Sphenophyllum cuneifolium (Sternberg 1821) Zeiller 1878-1879

(Fig. 7a)

Remarks. This form features cuneate leaves 5-15 mm long, 
six in a verticil, with slightly arching, dentate to deeply laciniate distal margins and straight to slightly convex lateral margins (Abbott 1958). Sphenophyllum cuneifolium has pronounced polymorphy (Darrah 1969), and may have been lianescent. Farther down the axis, leaves are progressively more deeply cleft both centrally to laterally, forming fingerlike lobes (Bell 1944; Abbott 1958). A single vein enters each leaf base and dichotomizes 2-4 times asymmetrically, with only one vein entering a distal tooth or lobe (Abbott 1958; Darrah 1969). Sphenophyllum emarginatum is larger, but the distal margins of its non-dissected leaves are obtusely triangular and appear rounded or crenulated to the naked eye. Sphenophyllum majus is considerably larger than Sphenophyllum cuneifolium, and Sphenophyllum oblongifolium has whorls of four equidimensional leaves with a pair of distinctly shorter leaves.

Sphenophyllum cuneifolium is known to occur from Langsettian to Bolsovian time (Cleal 2005). The single specimen of Sphenophyllum cuneifolium found in the new Wamsutta collections demonstrates that this genus was a rare member of the study area macroflora.

Order Cordaitales Campbell 1902

Family Cordaitaceae Grand'Eury 1877

Genus Cordaites Unger 1850

Cordaites cf. principalis (Germar 1848) Geinitz 1855

(Fig. 7b)

Remarks. This long-ranging species is distinguished by long strap-like leaves clustered near the top. The leaves have rounded and obtuse apices with fine veins and one to five "secondary veins". The trees are tall (up to about $30 \mathrm{~m}$, with trunks $1 \mathrm{~m}$ in diameter), and have primitive gymnosperm foliage (Janssen 1965; Darrah 1969). Complete, coriaceous, sword-like leaves may be $50 \mathrm{~cm}$ or more in length (Darrah 1969). Cordaites principalis may be confused with stems of Calamites spp., but horizontal nodes are lacking in the former.

Cordaites principalis is ubiquitous throughout the Upper Pennsylvanian strata of western Europe (Brousmiche Delcambre et al. 1998) and Atlantic Canada (Bashforth et al. 2014). Similar specimens are abundantly preserved as abandoned streambed detritus throughout the Pennsylvanian strata of the Narragansett Basin, although poor preservation prevents unequivocal identification at the species level. Nonetheless, these fossils indicate that arborescent cordaitaleans were a prominant component of the basin's tropical rainforests. In the Wamsutta Formation red beds, including those within the study area, leaves of Cordaites cf. principalis often overlie one another in a crisscrossed "jackstraw" fashion on interfluve channel substrates and in the "washes" of associated floodplains. Undulating veins, wrinkles and possible invertebrate traces are commonly observed on leaf surfaces.
Genus Artisia Presl in Sternberg 1838

\section{Artisia sp.}

(Fig. 7c)

Remarks. This taxon comprises the distinctly ribbed pith casts of cordaitalean stems (Josten 1991). Faster growing stems caused the pith to rupture, exposing transverse pith diaphragms at the points of septation (Janssen 1965; Darrah 1969).

Artisia is widely distributed in western Europe and North America. Despite the abundant occurrence of Cordaites cf. principalis leaves throughout the Wamsutta Formation red beds, Artisia is rarely found in the formation. Until now, Artisia has never been recorded in the Narragansett Basin.

Order Lepidodendrales Prantl 1883

Family Sigillariaceae Unger in Endlicher 1842

Genus Sigillaria Brongniart 1822

Sigillaria sp.

(Fig. 7d)

Remarks. The genus Sigillaria is distinguished from Lepidodendron by its possession of vertically-aligned, usually hexagonal leaf scars, separated by straight or undulating furrows extending the full length of the trunk (Janssen 1965; Josten 1991). Sigillaria was an arborescent lycopod related to modern clubmosses and quillworts. Up to $30 \mathrm{~m}$ in height, it had a straight, gently tapering, singly or sparsely branched trunk surmounted by a cluster of grass-like leaves. Petrified casts of Sigillaria trunks range up to almost $2 \mathrm{~m}$ in diameter (Janssen 1965).

Sigillaria dominated many Late Pennsylvanian tropical rainforest wetlands in western Europe and North America. Only one specimen of Sigillaria, however, was collected in the Wamsutta Formation study area (Fig. 7d). Its presence in a matrix of planar fluvial-channel sandstone suggests that the plant was tolerant of disturbances due to flooding. Despite the rarity of Sigillaria specimens, numerous leaves ( $C y$ perites) of arborescent lycopsids, probably associated with Sigillaria, were found by the authors (see below), frequently intermingled with various stems and other plant litter on shallow fluvial or wet and soggy floodplain substrates.

Genus Cyperites Lindley and Hutton 1832

\section{Cyperites sp.}

(Fig. 7e)

Remarks. The genus Cyperites comprises the long thin leaves of arborescent lycopsids (Janssen 1965), including Sigillaria (Bashforth 2005). They may have a "grass bladelike" appearance, with a prominent central vein, striae on both sides, and subparallel lateral margins (Josten 1991). 

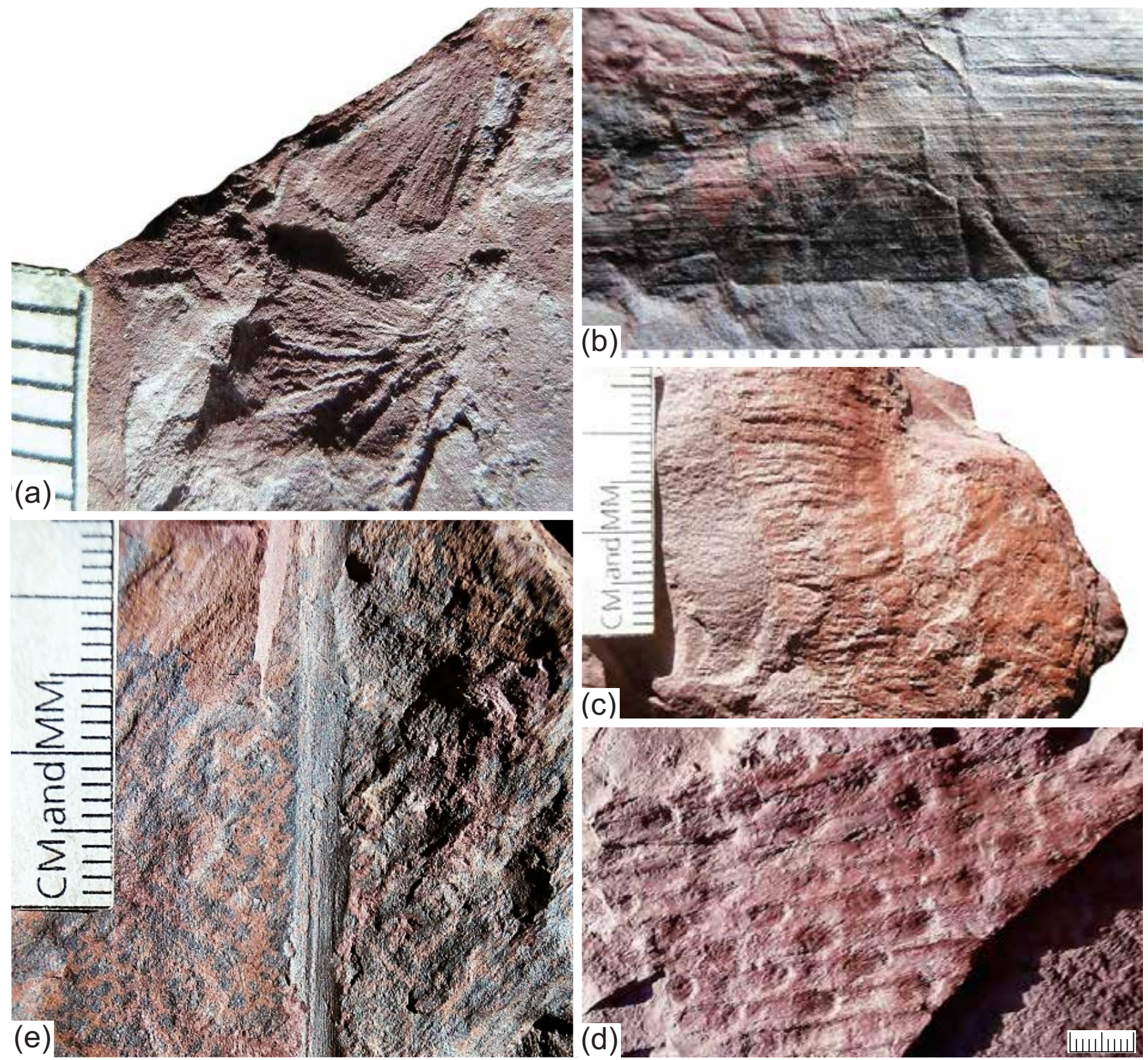

Figure 7. (a) HUPC No. 64,852, Sphenophyllum cuneifolium. Small size of leaflets and cuneiform terminal margin are characteristic. Scale in millimetres. (b) HUPC No. 64,896, Cordaites cf. principalis. Fine veins and very fine "secondary veins" are characteristic. Scale in millimetres. (c) HUPC No. 64,854, Artisia sp. Septate pith cast of a Cordaites stem. Scale in millimetres. (d) HUPC No. 64,850, Sigillaria sp. Note vertically aligned leaf scars. Scale equals $3 \mathrm{~cm}$. (e) HUPC No. 64,845, Cyperites. Long leaf with distinct medial vein and flanking striae. Scale in millimetres.

Cyperites may be distinguished from Calamites twigs and stems by the absence of horizontal nodes, and from Cordait$e s$ by its narrower width and the presence of a single distinct medial vein.

Cyperites is long-ranging, from Namurian to Stephanian, and is ubiquitous throughout tropical rainforest wetland strata of that interval worldwide. In the Wamsutta Formation of the study area, Cyperites is encountered as isolated leaves, or intermingled in an overlapping "jackstraw" fashion with Cordaites leaves, Calamites stalks and other parautochthonous stems on fluvial-channel and floodplain substrates.

\section{AGE OF THE WAMSUTTA FORMATION}

Stratigraphic ranges for 15 of the lower Wamsutta Formation taxa are given in Figure 8. In common with Knox 


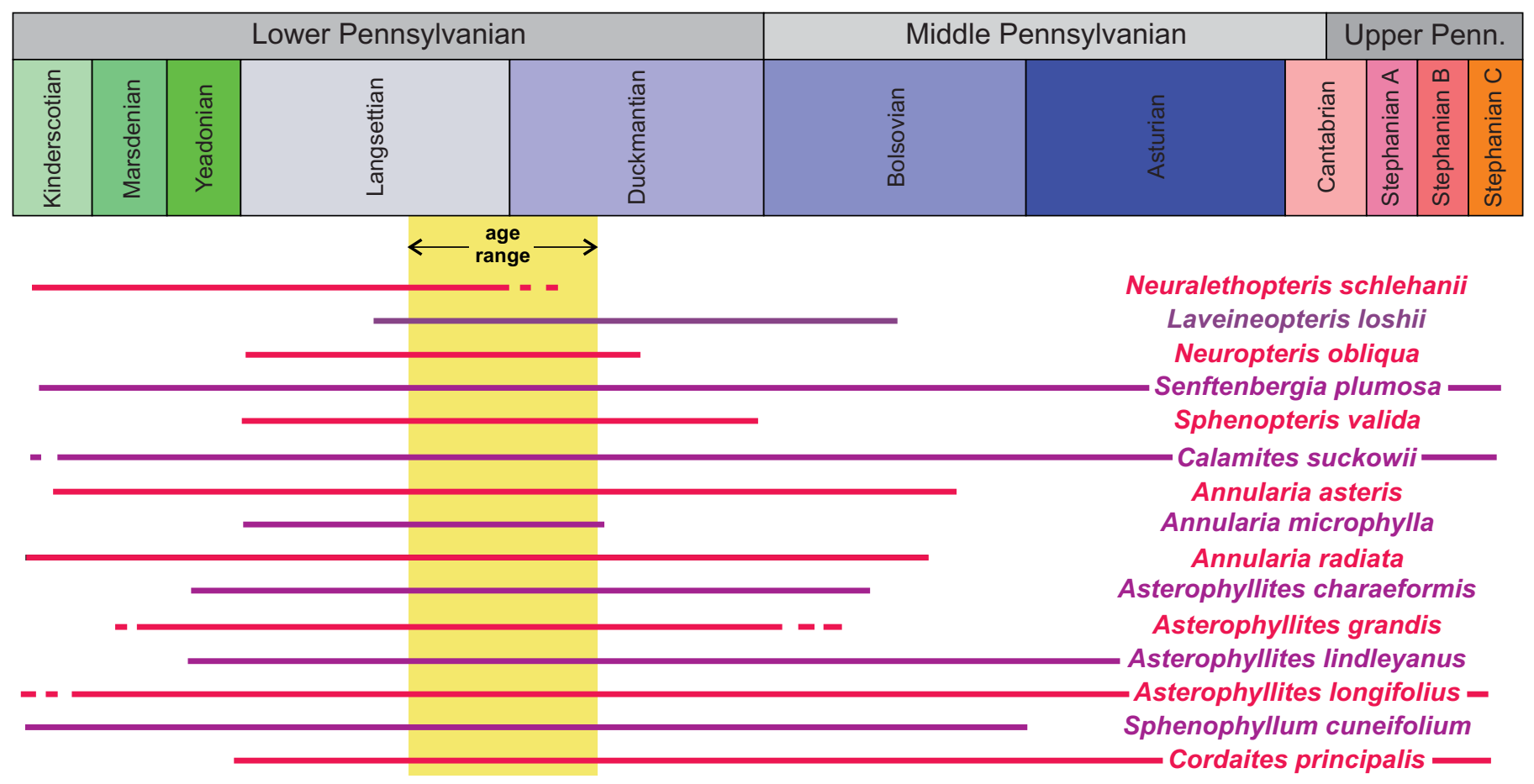

Figure 8. Chart depicting biostratigraphical ranges of 15 fossil-plant species collected in the Wamsutta Formation, inferred from known ranges in western Europe and the Maritime Provinces of Canada. Ranges following Brousmiche Delcambre et al. (1998), Cleal (2005), and Álvarez-Vázquez and Wagner (2017). Shaded-gold column shows the resultant age determination of the lower Wamsutta fossil macroflora, i.e., late Langsettian to early Duckmantian.

(1944), who first attempted to determine the age of the Wamsutta Formation through its fossil flora, we can confirm the presence of Calamocladus (=Asterophyllites lindleyanus), Cyperites (= lycopsid leaves) and Sphenopteris valida (=Sphenopteris artemisiaefolioides as indicated by Bell 1944). Of the florule reported by Knox, we did not find Annularia stellata or Neuropteris rarinervis Bunbury (= Laveineopteris rarinervis). With regard to the latter, Knox (1944) likely observed not Laveineopteris rarinervis but Neuropteris obliqua, one of the most common and morphologically variable taxa in the Wamsuttta Formation flora. Consequently, Knox erroneously concluded that his florule was of Asturian age, but Darrah (1969) determined it to be Bolsovian.

The macroflora reported in this paper (Table 1; Figs 3-7) correlates most closely with that of the Lower Pennsylvanian Cumberland Group of the Maritime Provinces. The Cumberland Group was assigned a late Langsettian to early Duckmantian age by Bell (1944); later Dolby (1997) assigned the Cumberland Group a late Yeadonian to Langsettian age based on palynological assemblages (Fig. 8). Bashforth et al. (2014) considered the Cumberland Group redbeds in New Brunswick to be mainly late Langsettian in age. Correlation to the Cumberland Group is indicated by the following plant-fossil species in the Wamsutta Formation: Neuralethopteris schlehanii, Neuropteris obliqua, Senftenbergia plumosa, Calamites suckowii, Annularia asteris, Annularia cf. microphylla, Asterophyllites charaeformis, Asterophyllites grandis, Asterophyllites lindleyanus, Sphenophyllum cuneifo- lium, and Sphenopteris valida.

Two aspects of the Wamsutta Formation macroflora are notable. First, the domination of cordaitaleans and sphenophytes (Table 1). The abundance of sphenophytes enables a detailed comparison with the assemblages recorded by Álvarez-Vázquez and Wagner's (2017) in the Maritime Provinces. We record many of the species that they listed, including three species of Annularia and four of Asterophyllites. Second, the next most common taxa in the Wamsutta Formation are the medullosan seed ferns (see Table 1), represented most abundantly by Neuropteris obliqua. This taxon is abundant in the Langsettian and Duckmantian strata of western Europe (Laveine 1967; Josten 1991). Bell (1944) also reports the presence of Neuropteris obliqua in the Cumberland Group.

The Wamsutta Formation macroflora reported here also resembles late Langsettian/early Duckmantian florules of the Iberian Peninsula, where there is a complete succession of Carboniferous macrofloral zones (Wagner and Álvarez-Vázquez 2010). At least thirteen of the twenty-two Wamsutta taxa that we report (Table 1) are listed by the latter authors in their Langsettian and Duckmantian macrofloral tables (their table 1, p. 257 and table 2, p. 266), including Neuropteris obliqua.

Finally, the presence in the Wamsutta macroflora of Laveineopteris cf. loshii and Neuralethopteris schlehanii further suggests a late Langsettian to early Duckmantian age for the lower Wamsutta Formation red beds. Regarding 
Laveineopteris loshii, Cleal and Thomas (1994) identified a Laveineopteris loshii Subzone, denoting the first appearances in Europe of Laveineopteris loshii in the middle Langsettian (and, by inference, its associated shade leaf Cyclopteris sp.; see Cleal and Shute 2003). Thus, the initial appearance of Laveineopteris cf. loshii suggests a biostratigraphic lower limit for the age of the lower Wamsutta Formation macro flora-i.e., middle Langsettian. On the other hand, Neuralethopteris schlehanii, a key marker species with a well-known range in western Europe (including the Iberian Peninsula) and North America (Goubet et al. 2000; Wagner and Álvarez-Vázquez 2010) suggests an upper limit for the age of the macroflora of the Wamsutta Formation in the study area-i.e., late Langsettian to early Duckmantian. This results from a general consensus that Neuralethopteris schlehanii became extinct abruptly at the close of the Langsettian substage (Goubet et al. 2000; Wagner and Álvarez-Vázquez 2010). However, there are a few reports of its occurrence in the early Duckmantian (e.g., Bell 1944).

\section{CONCLUSIONS}

The Early Pennsylvanian age of the macroflora in the lower Wamsutta Formation of the Narragansett Basin is more precisely defined on the basis of new plant-fossil collections from Red Rock Hill in North Attleboro, Massachusetts. Biostratigraphic comparisons of the new fossil flora with Middle Pennsylvanian tropical rainforest macrofloras in western Europe, especially those of the Iberian Peninsula where there is a complete succession of Late Carboniferous macrofloral zones, and with correlative tropical rainforest macrofloras of the Cumberland Group of the Maritime Provinces, reveal a late Langsettian to early Duckmantian age for the study area's Wamsutta fossil plants. Since the horizons in which the fossil plants were found are stratigraphically $100 \mathrm{~m}$ or more above the base of the Wamsutta Formation exposed in the area, the lowermost horizons were likely deposited wholly within Langsettian time.

Comprising a series of well-drained alluvial fans, the sedimentary rocks of the Wamsutta Formation red beds contain sparse plant fossils, which are usually fragmentary and poorly preserved. Nonetheless, a total of 22 plant macrofossil taxa are identified herein. Fossil-plant species reported for the first time in the Narragansett Basin, and occurring exclusively within the lower Wamsutta Formation, are the following: Neuralethopteris schlehanii, Annularia asteris, Annularia cf. microphylla, Annularia radiata, Asterophyllites grandis, Asterophyllites lindleyanus, and Artisia sp. The lower Wamsutta represents a seasonally dry (moist subhumid) upland fluvial environment with clastic sediment input that experienced repeated flooding. It supported a tropical rainforest, but was devoid of persistent swamps and peat deposits. The new collection of Wamsutta Formation macroflora, supplemented by a smaller collection assembled by Knox (1944), represent the oldest known macroflora within the Narragansett Basin.

\section{ACKNOWLEDGEMENTS}

We are indebted to E. S. Belt (Amherst College) for a copy of Bell (1944). P. R. Getty and H. B. Chase, Jr. graciously drafted some of the figures. J.-P. Laveine (Lille Museo) identified the specimens of all the seed ferns, C. Brousmiche-Delcambre (Université de Lille) identified all the sphenopterids, and R. H. Wagner (Cordoba) identified Senftenbergia plumosa. C. Cleal (National Museum Wales, Cardiff) also assisted the authors with useful comments. We are very grateful to these individuals. We thank the landowners for permission to collect specimens on their property at Red Rock Hill. I. Gregorio (Milton, Massachusetts), S. Emma (Providence, Rhode Island), and D. Papaliolios (Carlisle, Massachusetts) generously donated fossil plant specimens for our study. The helpful comments of J. Kukalova-Peck (Carleton University), R. Knecht (University of New Hampshire), O. Béthoux (Museum National d'Histoire Naturelle, Paris) and D. Wagner (University of Connecticut) are greatly appreciated. We also appreciate the graciousness of A. Knoll and S. Costanza in providing space in the Paleobotanical Collections at Harvard University for the specimens mentioned in this paper. Lastly, we thank the reviewers, A. Bashforth and C. ÁlvarezVázquez for their thorough reviews of this paper.

\section{EDITOR'S NOTE}

Due to the passing of the original corresponding author (Robert Sproule) during the completion of this manuscript, late-stage editing was carried out with the assistance of Patrick Getty, Arden Bashforth and Christopher Cleal. The editor would like to thank these individuals and Crystal Lyons for facilitating communication with Paul Lyons.

\section{REFERENCES}

Abbott, M.L. 1958. The American species of Asterophyllites, Annularia, and Sphenophyllum. Bulletins of American Paleontology, 38, pp. 289-390.

Álvarez-Vázquez, C. and Wagner, R.H. 2017. A revision of Annularia and Asterophyllites species from the lower Westphalian (Middle Pennsylvanian) of the Maritime Provinces of Canada. Atlantic Geology, 52, pp. 19-62. https://doi.org/10.4138/atlgeol.2017.002

Anderson, J.M., Anderson, H.M., and Cleal, C.J. 2007. Brief history of the gymnosperms: classification, biodiversity, phytogeography and ecology. Strelitzia, 20, pp. 1-280.

Artis, E.T. 1825. Antediluvian phytology, illustrated by a collection of the fossil remains of plants, peculiar to the coal formations of Great Britain. J. Cumberland, London, $24 \mathrm{pp}, 21 \mathrm{pl}$.

Bashforth, A.R. 2005. Late Carboniferous (Bolsovian) macroflora from the Barachois Group, Bay St. George Basin, southwestern Newfoundland, Canada. Palaeontographica Canadiana, 24, pp. 1-123, 20 pls. 
Bashforth, A.R., Cleal, C.J., Gibling, M.R., Falcon-Lang, H.J., and Miller, R.F. 2014, Paleoecology of Early Pennsylvanian vegetation on a seasonally dry tropical landscape (Tynemouth Creek Formation, New Brunswick, Canada). Review of Palaeobotany and Palynology, 200, pp. 229-263. https://doi.org/10.1016/j.revpalbo.2013.09.006

Bek. J. and Pšenička , J. 2001. Senftenbergia plumosa (Artis) emend. and its spores from the Carboniferous of the Kladno and Pilsen Basins, Bohemian Massif, and some related and synonymous taxa. Review of Palaeobotany and Palynology, 116, pp. 213-232. https://doi.org/10.1016/S00346667(01)00091-4

Bell, W.A. 1944. Carboniferous rocks and fossil floras of northern Nova Scotia. Geological Survey of Canada Memoir, 238, pp. 238-276. https://doi.org/10.4095/119859

Benner, J.S., Knecht, R.J., and Engel, M.S. 2015. Tonganoxichnus: a revision of the ichnogenus with new material from Massachusetts. In Ichnology: papers from ICHNIA. Edited by D. McIllroy. Geological Association of Canada, Miscellaneous Publication 9, pp. 31-43.

Brongniart, A. 1822. Sur la classification et la distribution des végétaux fossils en général, et sur ceux des terrains de sédiment supérieur en particulier. Mémoires du Muséum d'Histoire Naturelle, 8, pp. 203-240, 297-348, pl. 1-6.

Brongniart, A. 1828a. Prodrome d'une histoire des végétaux fossiles. F.G. Levrault, Paris, 223 pp.

Brongniart A. 1828b. Histoire des végétaux fossiles, ou recherches botaniques et géologiques sur les végétaux renfermés dans les diverses couches du globe, vol. 1, part 2. G. Dufour, Paris, pp. 81-136, pl. 9bis, 10, 12, 15, 19-27.

Brongniart, A. 1831. Histoire des végétaux fossiles, ou recherches botaniques et géologiques sur les végétaux renfermés dans les diverses couches du globe, vol. 1, part 5 , pp. 209-248, pl. 50, 53, 57, 58, 61bis, $62,64,65,67,68,70$, $71,73,76$.

Brongniart, A., 1833-1834, Histoire des Végétaux Fossiles, ou Recherches Botaniques et Géologiques sur les Végétaux Renfermés dans les Diverses Couches du Globe: Paris, G. Dufour, vol. 1, parts 7-9, p. 265-336, pls. 82A, 83-114, 117, 118, 124, 127, 128, 130.

Brousmiche Delcambre, C., Mercier, D., and Coquel, R. 1998. The Carboniferous flora from Briançonnais: a revision. Stratigraphical consequences. Second part: north of Briançon between Guisane and Clarée valleys. Paleontographica, Abteilung B, 248 (4-6), pp.87-125.

Campbell D. H. 1902. A university text-book of botany. MacMillan, London, 579 pp.

Cleal, C.J. (Editor). 1991. Plant fossils in geological investigations: the Palaeozoic. Ellis Horwood, Chichester, U.K., $123 \mathrm{pp}$.

Cleal, C.J. 2005. The Westphalian macrofloral record from the cratonic central Pennines Basin, UK. Zeitschrift der deutschen Gesellschaft für Geowissenschaften, 156, pp, 387-401.

Cleal, C.J. and Shute, C.H. 2003. Systematics of the Late Carboniferous medullosalean pteridosperm Laveineopteris and its associated Cyclopteris leaves. Palaeontology,
46 (2), pp. 353-411, 11 pls.

Cleal, C.J. and Thomas, B.A. 1994. Plant fossils of the British Coal Measures. The Palaeontological Association, London. Palaeontological Association Field Guides to Fossils, no. 6, $222 \mathrm{pp}$.

Cleal, C.J., Shute, C.H. and Zodrow, E.L. 1990. A revised taxonomy for Palaeozoic neuropterid foliage. Taxon 39, pp. 486-492. https://doi.org/10.2307/1223109

Corda, A.C.J. 1845. Beiträge zur Flora der Vorwelt. J.C. Calvesche Buchhandlung, Prague, 128 pp. https://doi. org/10.5962/bhl.title.141710

Corsin, P. 1960. Classification des ptéridophytes et des ptéridospermophytes du Carbonifère. Bulletin de la Société Géologique de France (Série 7), 2, pp. 566-572.

Cremer, L. 1893. Über die Fossilen Farne des Westfälischen Carbons und ihre Bedeutung für eine Gliederung des letzteren. Inaugural dissertation (Marburg), 49 pp., pl. I-III.

Darrah, W.C. 1969. A critical review of the Upper Pennsylvanian floras of eastern United States with notes on the Mazon Creek flora of Illinois. Privately published, Gettysburg, U.S.A., 220 pp., 80 pl.

Davidov, V., Crowley, J.L., Schmitz, M., and Poletaev, V.I. 2010. High-precision $\mathrm{U}-\mathrm{Pb}$ zircon age calibration of the global Carboniferous time scale and Milankovitch band cyclicity in the Donets Basin, eastern Ukraine, Geochemistry Geophysics Geosystems, 11 (2), pp. 1-22. https:// doi.org/10.1029/2009GC002736

Dawson, J.W. 1868. Acadian geology or the geology of Nova Scotia, New Brunswick and Prince Edward Island. $2^{\text {nd }}$ edition. Oliver and Boyd, Edinburgh, $694 \mathrm{pp}$.

Dolby, G. 1997. Palynological analysis of Carboniferous outcrop and corehole samples from the NATMAP Program, 1996 Field Season (Section 5-C, St. Peter). Unpublished Geological Survey of Canada Report 96-21, 27-36.

Du Mortier, B.-C. 1829. Analyse des familles des plantes, avec l'indication des principaux genres qui s'y rattachent. J. Casterman, Tournay, France, 104 pp. https:// doi.org/10.5962/bhl.title.48702

Dvořák, J. and Růžička, B. 1961. Geologická minulost Země: uvod do historické geologie a paleontologie. Státní nakladatelství technické literatury, Prague, 334 pp.

Eggert, D.A. and Taylor, T.N. 1966. Studies of Paleozoic ferns: on the genus Tedelea gen. nov. Palaeontographica Abteilung B, 118 (1-3), pp. 52-73.

Endlicher, S.L. 1842. Genera plantarum secundum ordines naturales disposita, supplementum secundum. F. Beck, Vienna, $114 \mathrm{pp}$.

Engler, A. and Prantl, K. 1902. Die natürlichen Pflanzenfamilien nebst ihren Gattungen und wichtigeren Arten, insbesondere den Nutzpflanzen, unter Mitwirkung zahlreicher hervorragender Fachgelehrten. Teil 1, Abteilungen 4 (Embryophyta asiphonogama (Abt. III)). W. Engelmann, Leipzig, 808 pp.

Falcon-Lang, H., Benton, M.J., Braddy, S.J., and Davies, S.J. 2006. The Pennsylvanian tropical biome reconstructed from the Joggins Formation of Nova Scotia, Canada. 
Journal of the Geological Society, 163 (3), pp. 561-576. https://doi.org/10.1144/0016-764905-063

Falcon-Lang, H., Gibling, M., Benton, M.J., Bashforth, A.R. 2010. Diverse tetrapod trackways in the Lower Pennsylvanian Tynemouth Creek Formation, near St. Martins, southern New Brunswick, Canada. Palaeogeography, Palaeoclimatology, Palaeogeography, 296, pp. 1-13. https:// doi.org/10.1016/j.palaeo.2010.06.020

Geinitz, H.B. 1855. Die Versteinerungen der Steinkohlenformation in Sachsen. Leipzig, $61 \mathrm{pp}$.

Germar, E.F. 1848. Die Versteinerungen des Steinkohlengebirges von Wettin und Löbejün im Saalkreise, vol. 5. p. 49-59, pls. 21-25; C. A. Schwetschke und Sohn, Halle, Germany.

Getty, P.R., Sproule, R., Wagner, D.L., and Bush, A.M. 2013. Variation in wingless insect trace fossils: insights from neoichnology and the Pennsylvanian of Massachusetts. Palaios, 28, pp. 243-258. https://doi.org/10.2110/ palo.2012.p12-108r

Getty, P.R., Sproule, R., Stimson, M.R., and Lyons, P.C. 2017. Invertebrate trace fossils from the Pennsylvanian Rhode Island Formation of Massachusetts, USA. Atlantic Geology, 53, pp. 185-206. https://doi.org/10.4138/atlgeol.2017.007

Göppert, H.R. 1844. Uebersicht der fossilen Flora Schlesiens. In Flora von Schlesien preussischen und österreichischen Antheils, vol. II, Ed. 2. Edited by F. Wimmer. Hirt, Breslau, pp. 159-225.

Göppert, H.R. 1848. Index palaeontologicus, oder Uebersicht der bis jetzt bekannten fossilen Organismen, unter Mitwirkung von Heinrich Robert Göppert und Hermann Meyer bearbeitet. E. Schweizerbart, Stuttgart.

Goubet, P., Pfefferkorn, H.W., and Gillespie, W.H. 2000. Neuralethopterids (trigonocarpalean pteridosperms) from the Early Pennsylvanian of eastern North America. PaleoBios, 20 (3), pp.11-37.

Grand'Eury, F.C. 1877. Mémoire sur la flore carbonifère du département de la Loire et du centre de la France, étudiée aux trois points de vue botanique, stratigraphique et géognostique. Mémoires presentés par divers savants à l'Académie des Sciences de l'Institut de France, Sciences Mathématiques et Physiques, 24 (1), 624 pp., $34 \mathrm{pl}$.

Janssen, R.E. 1965. Leaves and stems from fossil forests. Illinois State Museum Popular Science Series, 1, 190 pp.

Josten, K-H. 1991. Die Steinkohlen-Floren Nordwestdeutschlands. Fortschritte in der Geologie von Rheinland und Westfalen, Band 36, 434 pp.

Knecht, R.J. and Benner, J.S. 2008. Early- to Mid-Pennsylvanian vertebrates of an intermontane basin inferred from tracks and trackways of the Wamsutta Formation, southeastern New England. Geological Society of America Abstracts with Programs, 40, p. 370.

Knecht, R., Engel, M.S., and Benner, J.S. 2011. Late Carboniferouus paleoichnology reveals the oldest full-body impression of a flying insect. Proceedings of the National Academy of Sciences, 108, pp. 6515-6519. https://doi. org/10.1073/pnas.1015948108
Knox, A.S. 1944. A Carboniferous flora from the Wamsutta Formation of southeastern Massachusetts. American Journal of Science, 242, pp. 1390-138. https://doi. org/10.2475/ajs.242.3.130

Laveine, J.-P. 1966. A propos de la classification des neuroptéridées. Compte rendus de l'Académie des Sciences, Série D, 262, pp. 1680-1683.

Laveine, J.-P. 1967. Contribution à l'étude de la flore du terrain houiller. I. Flore fossile, Part 5. Les neuroptéridées du nord de la France: études géologiques pour l'Atlas de topographie souterraine. Service géologique des houillères du Bassin du Nord et du Pas-de-Calais, pp. 1-344 , pl. 1-84.

Lesquereux, L. 1884. Description of the coal flora of the Carboniferous formations in Pennsylvania and throughout the United States. Second Geological Survey of Pennsylvania, Report of Progress, P3, pp. 695-977, pl. 88-111.

Lindley, J. and Hutton, W. 1832. The fossil flora of Great Britain, or figures and descriptions of the vegetable remains found in a fossil state in this country. V. 1. James Ridgway and Sons, London, pp. 49-166.

Lynn, E.R. and Kroll, M.A. 2006. Microstructural analysis of the Rhode Island Formation from the Somerset drill core, Narragansett Basin, MA: evidence for Alleghenian upper greenschist-facies metamorphism and deformation. Geological Society of America Abstracts with Programs, 43, p. 105.

Lyons, P.C. 1977. Report on the bedrock geology of the Narragansett Basin, Massachusetts and Rhode Island. United States Geological Survey Open File Report 77-816, pp. 1-38.

Lyons, P.C. and Chase, H.B., Jr. 1976. Coal stratigraphy and flora of the northwestern Narragansett Basin. In A Guidebook for Field Trips to the Boston Area and Vicinity. Edited by B. Cameron. New England Intercollegiate Geologic Conference, 68th Annual Meeting, Boston, pp. 405-427.

Lyons, P.C., Tiffney, B., and Cameron, B. 1976. Early Pennsylvanian age of the Norfolk Basin, southeastern Massachusetts, based on plant megafossils. In Studies in New England Geology (C. Wroe Wolfe volume). Edited by P.C. Lyons and A.H. Brownlow. Geological Society of America Memoir 146, pp. 181-197.

Maria, A. and Hermes, D. 2001. Volcanic rocks in the Narragansett Basin, southeastern New England: petrology and significance to early formation. American Journal of Science, 301, pp. 286-312. https://doi.org/10.2475/ ajs.301.3.286

Matthew, G.F. 1906. A review of the flora of the Little River Group. Transactions of the Royal Society of Canada, 12 (4), pp. 99-149.

Meyen, S.V. 1978. An attempt at a radical improvement of suprageneric taxonomy of fossil plants. Phyta, 1, pp. 76-86.

Meyen, S.V. 1987. Fundamentals of palaeobotany. Chapman \& Hall, New York, 432 pp. https://doi.org/10.1007/97894-009-3151-0

Mosher, S. 1983. Kinematic history of the Narragansett Basin, Massachusetts and Rhode Island: constraints on late 
Paleozoic plate reconstruction. Tectonics, 2, pp. 327-344. https://doi.org/10.1029/TC002i004p00327

Mosher, S. and Rast, N. 1984. The deformation and metamorphism of Carboniferous rocks in Maritime Canada and New England. Geological Society of London, Special Publications, 14, pp. 233-243. https://doi.org/10.1144/ GSL.SP.1984 .014.01.21

Murray, D.P., Skehan, J.W., and Raben, J. 2004. Tectonostratigraphic relationships and coalification trends in the Narragansett and Norfolk basins, New England. Journal of Geodynamics, 37, pp. 583-611. https://doi.org/10.1016/j. jog.2004.02.006

Mutch, T.A. 1968. Pennsylvanian nonmarine sediments of the Narragansett Basin, Massachusetts-Rhode Island. In Late Paleozoic and Mesozoic continental sedimentation, northeastern North America. Edited by G. de V. Klein. Geological Society of America Special Paper 106, pp. 177-209. https://doi.org/10.1130/SPE106-p177

Oleksyshyn, J. 1976. Fossil plants of Pennsylvanian age from northwestern Narragansett Basin. In Studies in New England geology. Edited by P.C. Lyons and A.H. Brownlow. Geological Society of America Memoir, 146, pp. 143-179.

Potonié, H. 1900. Cycadofilices und sonstige Mittelgruppen zwischen Filicales und höheren Gruppen. In Die natürlichen Pflanzenfamilien. Edited by A. Engler and K. Prantl. W. Engelmann, Leipzig, pp. 780-798.

Prantl, K.A.E. 1883. Lehrbuch der Botanik für mittlere und höhere Lehrenstalten ( 5 th edition). Engelmann, Leipzig, $335 \mathrm{pp}$.

Pšenička, J. and Bek, J. 2003. Cuticles and spores of Senftenbergia plumosa (Artis) Bek and Pšenička from the Carboniferous of Pilsen Basin, Bohemian Massif. Review of Palaeobotany and Palynology, 125, pp. 299-312. https:// doi.org/10.1016/S0034-6667(03)00006-X

Quinn, A.W. and Oliver, W.A. Jr. 1962. Pennsylvanian rocks in New England. In Pennsylvanian System in the United States, a symposium. Edited by C.C. Branson. American Association of Petroleum Geologists, Tulsa Oklahoma, pp. 60-73.

Rich, B.H. 2006. Permian bulk shortening in the Narragansett Basin of southeastern New England, USA. Journal of Structural Geology, 28, pp. 682-694. https://doi. org/10.1016/j.jsg.2006.01.003

Sauveur, M. 1848. Végétaux fossiles des terrains houillers de la Belgique. Mémoires de l'Académie Royale des Sciences, des Lettres et des Beaux-Arts de Belgique, pls 1-36.

Schimper, W.P. 1869. Traité de paléontologie végétale ou la flore du monde primitif dans ses rapports avec les formations géologiques et la flora du monde actuel. part I. J.B. Baillière et Fils, Paris, 738 pp.

Scudder, S.H. 1893. Insect fauna of the Rhode Island Coal Field, Bulletin of the United States Geological Survey, no. $101,26 \mathrm{p}$.

Shaler, N.S., Woodworth, J.B., and Foerste, A.F. 1899. Geology of the Narragansett Basin. United States Geological Survey Monograph 33, 402 p. https://doi.org/10.5962/ bhl.title.66965
Skehan, J.W., S.J., Murray, D.P., Hepburn, J.C., Billings, M.P., Lyons, P.C., and Doyle, R.G. 1979. The Mississippian and Pennsylvanian (Carboniferous) systems in the United States-Massachusetts, Rhode Island, and Maine. United States Geological Survey Professional Paper, 1110A, pp. A1-A30.

Sproule, R. and Getty, P.R. 2012. Stephanian tetrapod ichnofossils and a triplosobid wing from the Narragansett Basin of Attleboro, Massachusetts, USA. Geological Society of America Abstracts with Programs, Northeastern Section, 44, p. 92.

Sternberg, K.M. 1821. Versuch einer geognostisch-botanischen Darstellung der Flora der Vorwelt, F. Fleischer, Leipzig, 1 (2), 33 pp., pl. 14-26.

Sternberg, K.M. 1825. Versuch einer geognostisch-botanischen Darstellung der Flora der Vorwelt, A-E. Ernst Brenck's Wittwe, Regensburg, 1 (4), 48 pp, pl. 40-59.

Sternberg, K.M. 1838. Versuch einer geognostisch-botanischen Darstellung der Flora der Vorwelt: Prague, Gotlieb Hässe Söhne, 2 (7/8), pp. 81-220, pls. 1-68.

Stopes, M.C. 1914. The "Fern Ledges" Carboniferous flora of St. John, New Brunswick. Geological Survey of Canada, Memoir 41, pp. 11-42, pl. 1-25.

Stur, D. 1877. Beiträge zur Kenntniss der Flora der Vorwelt. Die Culm-Flora der Ostrauer und Waldenburger Schichten. Abhandlungen der Kaiserlichen Königlichen Geologischen Reichsanstalt, 8 (2), pp. 107-472, pl. XVIII-XLIV.

Stur, D. 1885. Beiträge zur Kenntniss der Flora der Vorwelt. II. Die Carbon-Flora der Schatzlarer Schichten. Abhandlungen der Kaiserlich Königlichen Geologischen Reichsanstalt, 11, 1-418, pl. I-LXV.

Thompson, M.D., and Hermes, O.D. 2003. Early rifting in the Narragansett Basin, Massachusetts - Rhode Island: evidence from Late Devonian bimodal volcanic rocks. The Journal of Geology, 111, pp. 597-604. https://doi. org/10.1086/376768

Towe, K.M.1959. Petrology and source of sediments in the Narragansett Basin of Rhode Island and Massachusetts. Journal of Sedimentary Petrology, 29, pp. 503-512.

Unger, F. 1840. Abhandlung über die Struktur des Calamites und ihre Rangordnung im Gewächsreiche. Flora, 2, pp. 654-662.

Unger, F. 1850. Genera et species plantarum fossilium. Wilhelmum 4 Braumüller, Vienna, 627 pp.

Wagner, R.H. 1964. Stephanian B flora from the Ciñera-Matallana Coalfield (León) and neighbouring outliers. II: Mixoneura, Reticulopteris, and Odontopteris. Notas y Comunicaciones del Instituto Geológico y Minero de España, no. 75, pp. 5-56, pl. 10-19.

Wagner, R.H. and Álvarez-Vázquez, C. 2010. The Carboniferous floras of the Iberian Peninsula: a synthesis with geological connotations. Review of Palaeobotany and Palynology, 162, pp. 239-324. https://doi.org/10.1016/j. revpalbo.2010.06.005

Wagner, R.H. and Lyons, P.C. 1997. A critical analysis of the higher Pennsylvanian megafloras of the Appalachian region. Review of Palaeobotany and Palynology, 95, pp. 
255-283. https://doi.org/10.1016/S0034-6667(96)00037-1 Willard, B. and Cleaves, A.B. 1930. Amphibian footprints from the Pennsylvanian of the Narragansett Basin. Geological Society of America Bulletin, 41, pp. 321-327. https://doi.org/10.1130/GSAB-41-321

Zeiller, R. 1878-1879. Explication de la carte géologique de la France, tome quatrième, seconde partie, végétaux fossiles du Terrain Houiller. Service de la Carte Géologique de la France, Paris, p. 1-185 (1879), pls. CLIX-CLXXVI (1878).

Zeiller, R. 1879. Presentation de l'atlas du tome IV de l'ex- plication de la Carte Géologique de la France, et note sur le genre Mariopteris. Bulletin de la Société Géologique de France (Série 3), 7, pp. 92-99.

Zeiller, R. 1886-1888. Bassin houiller de Valenciennes. Description de la flore fossile. Études des Gîtes Minéraux de la France, pp. 1-729 (1888), pl. 1-94 (atlas, 1886).

Zen, E-An, Goldsmith, R., Ratcliffe, N.M., Robinson, P., Stanley, R.S., Hatch, N.L., Shride, A.F., Weed, E.G.A., and Wones, D.R. 1983. Bedrock geologic map of Massachusetts. The Commonwealth of Massachusetts, Department of Public Works, scale 1:250 000.

Editorial responsibility: Robert A. Fensome 